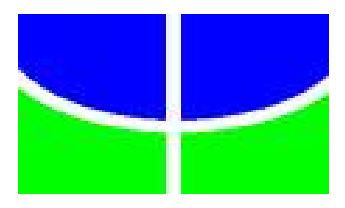

UNIVERSIDADE DE BRASÍLIA -UNB

INSTITUTO DE HUMANAS - IH

DEPARTAMENTO DE SERVIÇO SOCIAL - SER

\title{
TRÁFICO DE PESSOAS PARA FINS DE EXPLORAÇÃO SEXUAL NO BRASIL: ANÁLISE DAS AÇÕES DO ESTADO
}

TRABALHO DE CONCLUSÃO DE CURSO

Núbia Dias Cardoso Pereira

Matrícula: 02/90823

Brasília

Junho, 2007. 


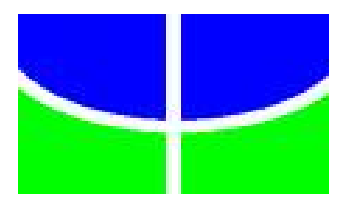

UNIVERSIDADE DE BRASÍLIA -UNB

INSTITUTO DE HUMANAS - IH

DEPARTAMENTO DE SERVIÇO SOCIAL - SER

\section{TRÁFICO DE PESSOAS PARA FINS DE EXPLORAÇÃO SEXUAL NO BRASIL: ANÁLISE DAS AÇÕES DO ESTADO}

Trabalho de Conclusão de Curso apresentado como requisito para a aquisição do grau de Assistente Social no curso de Serviço Social da Universidade de Brasília.

Orientadora: Professora Doutora Maria Lúcia Pinto Leal

Junho de 2007. 
TRÁFICO DE PESSOAS PARA FINS DE EXPLORAÇÃO SEXUAL NO BRASIL: ANÁLISE DAS AÇÕES DO ESTADO

Banca examinadora:

Profa. Doutora Maria Lúcia Pinto Leal (Orientadora)

Universidade de Brasília

Profa $^{a}$. Doutora Maria Auxiliadora César

Universidade de Brasília

Tatiana Silva Estrela

Assistente Social

Instituto Marista de Solidariedade 


\section{Agradecimentos}

Primeiramente a Deus que, pela sua Graça e Misericórdia, me concedeu a vida.

Aos meus pais, que sempre acreditaram em mim e me educaram da melhor maneira possível.

A todos os profissionais que ajudaram na concretização deste trabalho.

Agradeço à professora Maria Lúcia Pinto Leal pela atenção dispensada, orientando e compartilhando seus conhecimentos sempre com tranqüilidade e profissionalismo. 


\section{SUMÁRIO}

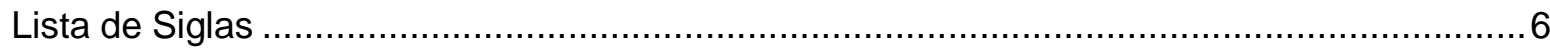

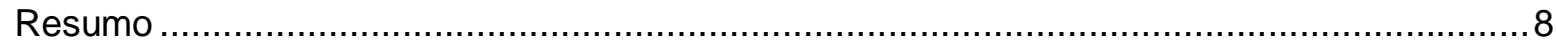

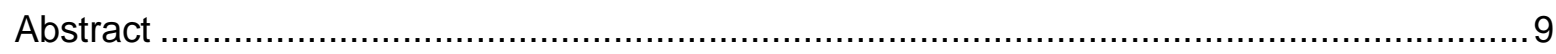

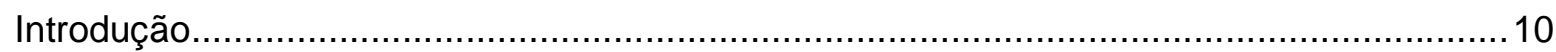

1. Referencial Conceitual- Metodológico..................................................................... 13

2. O Tráfico de Seres Humanos para fins de Exploração Sexual: cercando o objeto ............17

3. Ações de Enfrentamento ao Tráfico: resposta do Estado às recomendações da PESTRAF

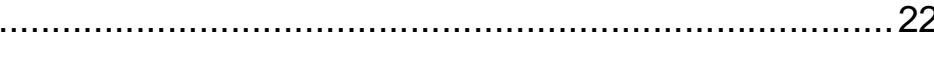

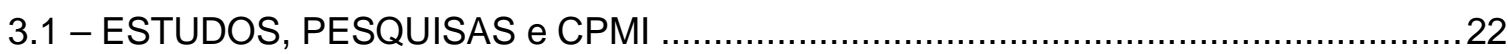

Diagnóstico sobre Tráfico de Seres Humanos em São Paulo, Rio de Janeiro, Goiás e

Ceará.

Indícios de Tráfico de Pessoas no universo de deportadas e não admitidas que ingressam no Brasil via o aeroporto de Guarulhos ................................................. 24

O Tráfico de Seres Humanos no Estado do Rio Grande do Sul ....................................2 28

CPMI da Exploração Sexual de Crianças e Adolescentes..............................................30

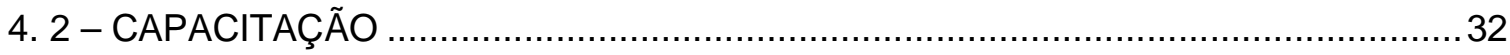

Manual - Tráfico de Pessoas Para Fins de Exploração Sexual ........................................32

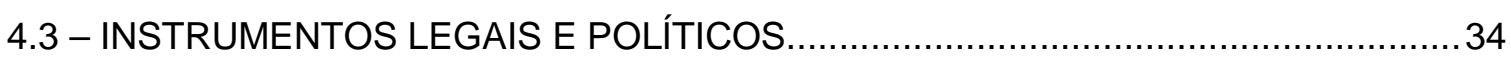

Alteração do Código Penal Brasileiro ................................................................... 34

Política Nacional de Enfrentamento ao Tráfico de Pessoas ........................................... 36

I Seminário Luso-Brasileiro sobre Tráfico de Pessoas e Imigração llegal ......................39

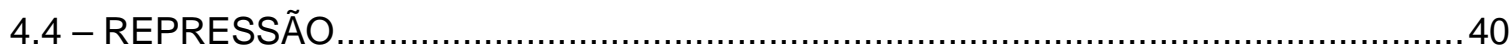

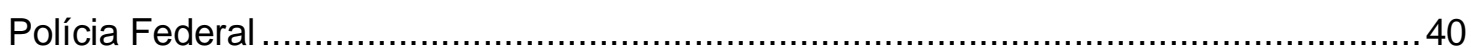

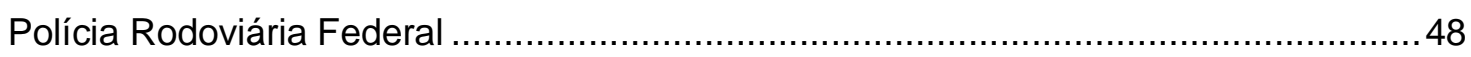

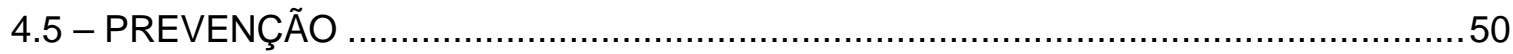

Disque Denúncia Nacional de Abuso e Exploração Sexual de Crianças e Adolescentes

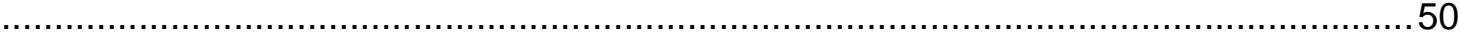

Campanha Nacional de Combate ao Tráfico de Seres Humanos................................54

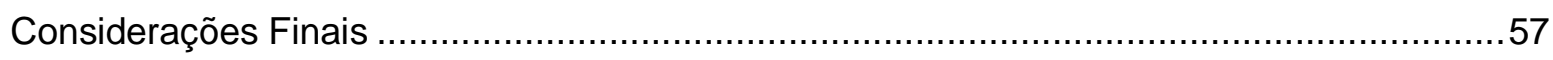

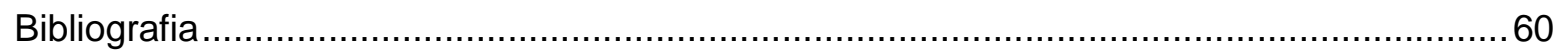

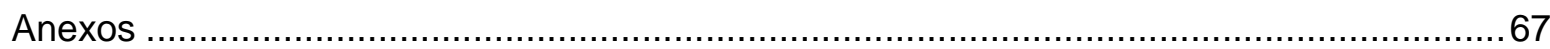




\section{Lista de Siglas}

\begin{tabular}{|c|c|}
\hline ABRAPIA & $\begin{array}{l}\text { Associação Brasileira Multiprofissional de Proteção à Infância e à } \\
\text { Adolescência }\end{array}$ \\
\hline$A C$ & Acre \\
\hline$A L$ & Alagoas \\
\hline AM & Amazonas \\
\hline ANVISA & Agência Nacional de Vigilância Sanitária \\
\hline ASBRAD & Associação Brasileira de Defesa da Mulher \\
\hline BA & Bahia \\
\hline CE & Ceará \\
\hline CECRIA & Centro de Referência, Estudos e Ações sobre Crianças e Adolescentes. \\
\hline CGDI & Coordenação Geral de Defesa Institucional \\
\hline $\mathrm{CP}$ & Código Penal \\
\hline $\mathrm{CPI}$ & Comissão Parlamentar de Inquérito \\
\hline CPMI & Comissão Parlamentar Mista de Inquérito \\
\hline CREAS & Conselho Regional de Assistência Social \\
\hline $\mathrm{DDH}$ & Divisão de Direitos Humanos \\
\hline DF & Distrito Federal \\
\hline DIEESE & Departamento Intersindical de Estatística e Estudos Socioeconômicos \\
\hline DP & Delegacia de Polícia \\
\hline DPF & Departamento de Polícia Federal \\
\hline DST & Doenças Sexualmente Transmissíveis \\
\hline ECA & Estatuto da Criança e do Adolescente \\
\hline ES & Espírito Santo \\
\hline GO & Goiás \\
\hline IBISS & Instituto Brasileiro de Inovação em Saúde Pública \\
\hline IBISS-CO & Instituto Brasileiro de Inovação em Saúde Pública no Centro Oeste \\
\hline INFRAERO & Infra-estrutura aeroportuária \\
\hline MA & Maranhão \\
\hline MG & Minas Gerais \\
\hline MP & Ministério Público \\
\hline MS & Mato Grosso do Sul \\
\hline MT & Mato Grosso \\
\hline OIT & Organização Internacional do Trabalho \\
\hline ONG & Organização Não-Governamental \\
\hline
\end{tabular}




\begin{tabular}{|l|l|}
\hline PA & Pará \\
\hline PB & Paraíba \\
\hline PE & Pernambuco \\
\hline PESTRAF & $\begin{array}{l}\text { Pesquisa sobre tráfico de Mulheres, Crianças e Adolescentes para fins de } \\
\text { Exploração Sexual Comercial. }\end{array}$ \\
\hline Petrobrás & Petróleo Brasileiro S.A. \\
\hline PF & Polícia Federal \\
\hline PI & Piauí \\
\hline PR & Paraná \\
\hline PRF & Polícia Rodoviária Federal \\
\hline REDESAP & Rede Nacional de Identificação de Crianças e Adolescentes desaparecidas \\
\hline RJ & Rio de Janeiro \\
\hline RN & Rio Grande do Norte \\
\hline RO & Rondônia \\
\hline RR & Roraima \\
\hline RS & Rio Grande do Sul \\
\hline SBT & Sistema Brasileiro de Televisão \\
\hline SC & Santa Catarina \\
\hline SE & Sergipe \\
\hline SEDH/PR & Secretaria Especial de Direitos Humanos \\
\hline SENASP & Secretaria Especial de Segurança Pública \\
\hline SP & São Paulo \\
\hline TO & Tocantins \\
\hline TSH & Tráfico de Seres Humanos \\
\hline UNODC & Escritório das Nações Unidas contra Drogas e Crimes \\
\hline & \\
\hline
\end{tabular}




\section{Resumo}

A existência de quadrilhas de aliciadores que atuam no Tráfico de Pessoas tem se mostrado cada vez mais recorrente na realidade brasileira e mundial. O fato de ser um crime muito lucrativo colabora para sua disseminação e dificulta o seu enfrentamento.

No ano de 2002 foi lançada no Brasil a PESTRAF, uma pesquisa responsável pela identificação de 241 rotas de tráfico de mulheres e adolescentes para fins de exploração sexual em todo o país, a qual também revelou a existência do tráfico internacional de pessoas, o que significou um grande avanço no combate a este crime. Ao final do estudo, a pesquisa listou algumas recomendações necessárias para a superação da questão.

A partir dessas recomendações, este estudo estará analisando as ações do Estado nos últimos 5 (cinco) anos.

Divididas em 5 (cinco) itens, foram analisadas 13 (treze) ações de maior repercussão desenvolvidas pelo Estado, no período de 2002 a 2007: a) Estudos, Pesquisas e CPMI; b) Capacitação contra o Tráfico de Pessoas para fins de Exploração Sexual; c) Instrumentos Legais e Políticos; d) Repressão ao Tráfico para fins de Exploração Sexual; e) Prevenção ao Tráfico de Pessoas para fins de Exploração Sexual.

Ao final de cada uma dessas ações, será exposto quadro resumo com seus pontos fracos e fortes.

$\mathrm{Na}$ última parte do trabalho, apresentaremos algumas considerações finais julgadas oportunas sobre a importância do Estado no enfrentamento ao Tráfico de Pessoas para fins de Exploração Sexual no Brasil, na esperança de que sirvam de reflexão para futuras ações a serem adotadas.

Palavras-Chaves : Tráfico de Pessoas, ações do Estado, PESTRAF. 


\begin{abstract}
The existence of group of criminals that act with the Traffic of People if has shown each more recurrent time in the Brazilian and world-wide reality. The fact of being a very lucrative crime collaborates for its dissemination and makes it difficult its confrontation.

In the year of 2002, the PESTRAF, a responsible research for the identification of 241 routes of traffic of Women was launched in Brazil and Adolescents for ends of sexual exploration in all the country, which also disclosed the existence of the international traffic of people, what it meant a great advance in the combat to this crime. To the end of the study, the research listed some necessary recommendations for the overcoming of the question.

To leave of these recommendations, this study it will be analyzing the actions of the State in last the 5 (five) years. Divided in 5 (five) itens, had been analyzed 13 (thirteen) actions of bigger repercussion developed by the State, in the period of 2002 the 2007: (a) Studies, Research and CPMI; b) Qualification against the Traffic of People for ends of Sexual Exploration; c) Legal instruments and Politicians; d) Repression to the Traffic for ends of Sexual Exploration; e) Prevention to the Traffic of People for ends of Sexual Exploration.

To the end of each one of these actions, picture will be displayed summary with its weak and strong points.

In the last part of the work, we will present some opportune considered on the importance of the State in the confrontation to the Traffic of People for ends of Sexual Exploration in Brazil, in the hope of that they serve of reflection future actions to be adopted.
\end{abstract}

Words - Key: Traffic of People, action of the State, PESTRAF. 


\section{Introdução}

O Tráfico de Seres Humanos não é uma questão recente na história brasileira, porém adentrou a agenda pública a partir de 2002, com a publicação da $\operatorname{PESTRAF}^{1}$, que comprovou a existência do tráfico internacional e interno de mulheres e adolescentes.

De acordo com a PESTRAF, existiam em 2002 cerca de 241 rotas internas e internacionais do tráfico de mulheres, crianças e adolescentes em todo o Brasil. "tais rotas podem utilizar-se de vias terrestres, aéreas, hidroviárias e marítimas. Elas são estrategicamente construídas a partir de cidades que estão próximas, ou que contam, com rodovias, portos e aeroportos, oficiais ou clandestinos, que são pontos de fácil mobilidade" (PESTRAF, 2002).

Apesar da ênfase dada às rotas internacionais, a PESTRAF demonstrou que, das 241 rotas existentes no país, 110 são interestaduais e intermunicipais, constatando que o tráfico interno é tão expressivo quanto o internacional, merecendo, assim, uma atenção especial na elaboração das políticas públicas para a área.

\begin{tabular}{|l||c||c||c||c|}
\hline Região de Origem & Internacional & Interestadual & Intermunicipal & Total \\
\hline \hline Sul & 15 & 09 & 04 & 28 \\
\hline \hline Sudeste & 28 & 05 & 02 & 35 \\
\hline \hline Centro-Oeste & 22 & 08 & 03 & 33 \\
\hline \hline Nordeste & 35 & 20 & 14 & 69 \\
\hline \hline Norte & 31 & 36 & 09 & 76 \\
\hline \hline Total & 131 & 78 & 32 & 241 \\
\hline
\end{tabular}

Fonte: PESTRAF, 2002.

"Segundo dados obtidos na pesquisa de campo realizada pelas Equipes da PESTRAF no território nacional: (a) na via terrestre, os meios de transporte mais utilizados são os táxis, os carros e os caminhões; (b) nos percursos hidroviários e marítimos, são usadas pequenas embarcações e navios; e (c) o percurso é feito com vôos charter's e modalidades" (PESTRAF, 2002).

De acordo com a Pesquisa, o tráfico internacional geralmente é realizado por rotas aéreas, seguidas pelas terrestres, quando nas rotas internas o predomínio é das vias terrestres.

\footnotetext{
${ }^{1}$ Pesquisa de âmbito nacional, realizada em 2002, onde foi diagnosticada a existência do tráfico nacional e internacional no Brasil, 241 rotas aéreas e terrestres, além de algumas recomendações, como possíveis propostas para o combate ao crime.
} 
A pesquisa ainda traça o perfil das vítimas, confirmando os dados da ONU quando afirmam que as brasileiras estão entre as principais vítimas do tráfico internacional para a exploração sexual e que, em sua maioria, são mulheres entre 18 e 30 anos, pois, de acordo com a PESTRAF "No Brasil, o tráfico para fins sexuais é, predominantemente, de mulheres e garotas negras e morenas, com idade entre 15 e 27 anos". Essas mulheres acreditam no sonho de uma vida melhor na Europa e se deixam levar por falsas promessas milagrosas.

"Cerca de 90\% dos casos são de mulheres brasileiras que estão indo para a indústria do sexo na Europa" disse o Coordenador do Programa de Prevenção ao Crime e Redução da Oferta de Drogas, Reiner Pugs.

Nesta perspectiva, esse estudo trata de analisar as ações de enfrentamento2 ao tráfico de pessoas para fins de exploração sexual, no período de 2002 a 2007, tendo como referência as recomendações3 da PESTRAF 2002.

Dentre as várias recomendações, 11 (onze) delas ocuparam um lugar especial neste estudo e estão agrupadas nos seguintes itens: Estudos, Pesquisas e CPMI; Capacitação contra o Tráfico de Pessoas para fins de Exploração Sexual; Instrumentos Legais e Políticos; Repressão ao Tráfico para fins de Exploração Sexual e Prevenção ao Tráfico de Pessoas para fins de Exploração Sexual.

A presente monografia constituir-se-á em 3 (três) Capítulos, considerações finais, bibliografia e anexos, além dessa introdução, onde estará sendo apresentado o objetivo principal, a justificativa e uma breve contextualização.

O segundo capítulo traz o referencial teórico-metodológico, com conceitos importantes para a definição e elucidação dessa questão, além de detalhar o método utilizado para a realização da pesquisa. Ainda nesse capítulo serão levados em consideração os acordos firmados, as leis existentes, além de pareceres de pesquisadores da área.

O segundo Capítulo trata do apanhado histórico do tráfico de pessoas para fins de exploração sexual e suas peculiaridades no transcorrer do tempo, valores que se modificaram e avanços ideológicos que acabaram por criminalizar o tráfico e a exploração

\footnotetext{
2 "Na perspectiva de nosso estudo, o termo enfrentar assume um sentido político, que abrange desde o reconhecimento de como a questão do tráfico para fins de exploração sexual comercial apresenta-se em suas múltiplas dimensões - política, social, jurídica e sociocultural - até a concretização de ações no âmbito das políticas públicas, visando à defesa e à garantia dos direitos das mulheres, crianças e adolescentes vítimas desta forma de violência" (PESTRAF 2002, p.123).

${ }^{3}$ Recomendações da PESTRAF: vide anexo I
} 
sexual. Alguns dados quantitativos também serão expostos na perspectiva de contribuírem para um melhor entendimento sobre o tema.

No terceiro capítulo, estarão as principais ações, propriamente ditas, com datas, objetivos e modus operandi de cada uma delas, seguidas de um quadro resumo, onde se encontram os pontos fortes e fracos de cada uma dessas ações.

Nas considerações finais, encontram-se as principais conclusões da pesquisa sobre o assunto, esperando-se ter chegado a uma conclusão coerente com a realidade e dando um parecer sobre a importância do papel do Estado e da sociedade civil nos últimos 5 anos no que diz respeito ao enfrentamento do crime de tráfico para exploração sexual e avaliando os sucessos e as derrotas no combate ao crime.

Com a elaboração desse estudo, espera-se adquirir uma visão não só jurídica sobre este tema, mas construir uma visão social crítica capaz de cobrar do Estado uma atitude mais presente e coerente, e não apenas medidas emergenciais e descontextualizadas, como há muito se tem feito. 


\section{Referencial Conceitual- Metodológico}

A abordagem metodológica teve como referência o levantamento qualitativo, realizado por meio de fontes secundárias, sendo estas classificadas por Daniela Martins Simões ${ }^{4}$, como "aquelas que trazem informações colhidas em fontes primárias e remontam a épocas posteriores aos fatos estudados... livros, revistas, enciclopédias, jornais...", e consultas informais junto aos gestores envolvidos com a temática afim, além de consultas à internet.

As ações alcançadas por esta pesquisa, provenientes das recomendações da PESTRAF, foram estrategicamente agrupadas, para fins deste estudo, em cinco aspectos: o primeiro ponto são os Estudos, Pesquisas e CPMI, em respostas às seguintes recomendações da PESTRAF:

- "Realização de estudos e de diagnósticos, considerando as múltiplas dimensões do fenômeno (política, social, econômica, jurídica e sociocultural), ampliando a compreensão sobre a violência estrutural e privilegiando os recortes de classe, gênero, etnia e idade".

- "Investigação detalhada de crimes relacionados ao tráfico: desaparecimento; seqüestro; adoção ilegal; prostituição infanto-juvenil; turismo sexual; tráfico de drogas; organizações criminosas; e economias clandestinas".

- "Ação efetiva dos órgãos de segurança e da justiça, no sentido de investigar e punir os casos de tráfico, investigando e punindo exemplarmente os casos de conivência e/ou participação de autoridades e membros das elites locais".

Nesse primeiro ponto estão relatadas 3 (três) pesquisas realizadas em diferentes estados e a CPMI de Exploração Sexual de Crianças e Adolescentes: A primeira pesquisa "Diagnóstico sobre Tráfico de Seres Humanos em São Paulo, Rio de Janeiro, Goiás e Ceará" foi realizada nesses estados por considerá-los estratégicos e de muita importância para conhecer os perfis e enfrentar a questão. A segunda pesquisa "Indícios de Tráfico de Pessoas no universo de deportadas e não admitidas que ingressam no Brasil via o aeroporto de Guarulhos" foi realizada no principal aeroporto do país e tentou traçar, através da aplicação de questionários, o perfil das deportadas da Europa e que fazem parte da indústria do sexo. "O Tráfico de Seres Humanos no Estado do Rio Grande do Sul" é a terceira

\footnotetext{
${ }^{4}$ Professora da Faculdade Assis Gurgacz. Fonte:
} 
pesquisa realizada e mostra características do tráfico de pessoas naquele estado e a CPMI de Exploração Sexual de crianças e adolescentes traçou um mapa do crime do país, permitindo que a questão tomasse maior evidência na mídia e no governo.

O segundo ponto de ações a ser abordado é Capacitação contra o Tráfico de Pessoas para fins de Exploração Sexual e responde às seguintes recomendações da PESTRAF:

- "Sensibilização, mobilização e capacitação das pessoas que atuam no sistema de atendimento e nos espaços de defesa e de responsabilização".

- "Treinamento dos Conselheiros Tutelares e dos profissionais das Delegacias especializadas, priorizando a visibilidade, o entendimento e o combate ao fenômeno".

Neste segundo ponto, o objeto de estudo se restringe a apenas uma ação desenvolvida: o Manual "Tráfico de Pessoas para fins de Exploração Sexual", objeto do estudo, direcionado, principalmente, para policiais, juízes e promotores;

No terceiro conjunto estão os Instrumentos Legais e Políticos, e seguem às seguintes recomendações da PESTRAF:

- "Reforçar, no plano jurídico, os referenciais de combate ao tráfico, tais como o Código Penal Brasileiro...";

- "Definição de um Plano Nacional, contendo as principais diretrizes de atuação frente ao fenômeno";

- "Estabelecimento de acordos diplomáticos internacionais, através de protocolos de intenções, entre os países que foram apontados nas rotas de tráfico, tencionando estabelecer ações conjuntas para combater o tráfico de mulheres, crianças e adolescentes para fins sexuais".

Nesse tópico constam as alterações do Código Penal Brasileiro, a Política Nacional de Enfrentamento ao Tráfico de Pessoas, considerada uma das grandes vitórias no enfrentamento ao tráfico de pessoas, além das análises do acordo entre Brasil e Portugal e das Declarações provenientes do I Seminário Luso-Brasileiro sobre Tráfico de Pessoas e Imigração llegal.

O quarto ponto se atem às ações coercitivas do Estado, através das Polícias Federal e Rodoviária Federal, através do tópico Repressão ao Tráfico para fins de 
Exploração Sexual, onde os número de inquéritos, operações e prisões são alguns dos dados observados e seguem à seguinte recomendação da PESTRAF.

- "Ação efetiva dos órgãos de segurança e Justiça, no sentido de investigar e punir os casos de tráfico, investigando e punindo exemplarmente os casos de conivência e/ou participação de autoridades e membros de elites locais".

No quinto e último conjunto de ações estão as de Prevenção ao Tráfico de Pessoas para fins de Exploração Sexual e seguem as seguintes recomendações da PESTRAF:

- "Programas que incentivem a denúncia e garantam a segurança e a reinserção social das vítimas".

- "Elaboração e publicação de materiais de informações e de formação. Divulgação em massa (através de cartilhas, folder's e outros) nas escolas, nas boates, nas praias, nas agências de modelos e demais locais onde se encontram vítimas preferenciais, de informações sobre as formas de aliciamento para o tráfico de mulheres, crianças e adolescentes".

Neste grupo de ações estão duas importantes medidas adotadas: a primeira o serviço de "Disque Denúncia Nacional de Abuso e Exploração Sexual de Crianças e Adolescentes", sob a coordenação da SEDH/PR, e a "Campanha Nacional de Combate ao Tráfico de Seres Humanos", lançada em 2004, sob a gestão do Ministério da Justiça, com objetivo de conscientizar e prevenir a população em geral sobre o tráfico de pessoas para fins de exploração sexual.

Por se tratar de um estudo que busca resposta às recomendações contidas no Relatório da PESTRAF, publicado em 2002, este estudo corresponde ao período de 2002 a 2007, sendo esse também o motivo pelo qual a PESTRAF foi referenciada no presente trabalho.

Depois de toda esta pesquisa documental, foi realizada uma análise qualitativa e, na medida do possível, quantitativa, compilando e digitando os dados colhidos, procurando confrontar as propostas da PESTRAF com as ações do Governo Federal, assim como as de Organizações da Sociedade Civil, no que diz respeito ao enfrentamento ao Tráfico de Seres Humanos, com fins à exploração sexual. 
Vale salientar que para a sistematização e organização dos dados coletados na pesquisa, foi utilizado um instrumental que atribuiu pontos fracos e pontos fortes em relação às ações analisadas, desenvolvidas pelo Estado sob as recomendações da PESTRAF.

O termo Tráfico de Pessoas é aqui classificado, de acordo com o Protocolo de Palermo, art. $2^{\circ}$, alínea a, como:

“...o recrutamento, o transporte, a transferência, o alojamento ou a recolha de pessoas, pela ameaça de recursos, à força ou outras formas de coação, por rapto, fraude, e engano, abuso de autoridade ou de situação de vulnerabilidade, ou através da oferta ou da aceitação de pagamentos, ou de vantagens para obter o consentimento de uma pessoa que tenha autoridade sobre uma outra para fins de exploração".

Este também é o conceito amplamente utilizado e aceito pelos principais órgãos de combate, repressão e estudo em todo o mundo. De forma abrangente, o texto traz o conceito de tráfico para além das questões pontuais referentes à idade ou sexo, por exemplo, mas permite que todos, independentemente de características discriminatórias, se tornem possíveis vítimas do Tráfico de Pessoas.

No âmbito nacional, o conceito atualmente adotado pelo Código Penal Brasileiro está em seu artigo $n^{\circ} 231$ :

"Promover, intermediar ou facilitar a entrada, no território nacional, de pessoa que venha exercer a prostituição ou a saída de pessoa para exercê-la no estrangeiro".

Quando existe o envolvimento de crianças e adolescentes, o ECA criminaliza, em seu artigo 244-A, a submissão de criança ou adolescente à prostituição ou à exploração sexual, com pena de quatro a dez anos, e multa.

O debate sobre o Tráfico de Seres Humanos no Brasil ainda é uma temática muito recente, o que dificulta uma abordagem mais ampla e aprofundada sobre o tema, porém, nos últimos anos, esse tem sido constante motivo de discussão entre profissionais da área e grandes pesquisadores do tráfico de seres humanos, o que originou a criação de acordos e protocolos internacionais, além de estudos estratégicos por parte de especialistas na área.

É com base nesses documentos oficiais, estudos e legislações que se pautará esta pesquisa. 


\section{O Tráfico de Seres Humanos para fins de Exploração Sexual: cercando o objeto}

É fato que o Tráfico de Pessoas é uma prática muito antiga, porém só nos últimos anos tem se procurado dar a atenção devida a este crime que, de acordo com o Escritório das Nações Unidas contra Drogas e Crimes, a UNODC, movimenta por ano cerca de US\$ 7 a 9 bilhões, o que a classifica como a terceira atividade ilícita mais lucrativa do mundo, perdendo apenas para o tráfico de drogas e contrabando de armas.

Pode-se dizer que esse tipo de exploração é milenar e remonta dos primórdios da história, pois conta essa mesma história que os grandes conquistadores Alexandre Magno e Gênsis Khan, nos anos 356-323 a.C e 1167-1227, respectivamente, além das riquezas das terras conquistadas, se apossavam também das mulheres e dos homens, tanto para a satisfação dos ímpetos sexuais, como também para a realização de trabalhos forçados e escambos, já que a compra e venda de pessoas eram tidas como práticas comuns.

A própria Bíblia nos relata um fato que nos faz questionar se não seria um sinal da existência do tráfico de estrangeiros quando, em Gênesis capítulo 19, pessoas da cidade de Sodoma batem a porta de Ló e exigem que os estrangeiros que se encontram em sua casa sejam colocados à disposição deles para que fossem abusados, o que nos deixa a entender que esta era uma prática comum dentre aqueles moradores.

"Mas antes de se deitarem, os homens daquela cidade cercaram a casa, os homens de Sodoma, assim os moços como os velhos, sim, todo o povo de todos os lados;

e chamaram por Ló e Ihe disseram: Onde estão os homens que, à noitinha, entraram em tua casa? Traze-os fora a nós para que abusemos deles".

Gen. 19:4-5

$\mathrm{Na}$ história mais recente, durante a época das grandes navegações, o Brasil, na época colônia portuguesa, não fugiu à regra. Européias vinham para a América prostituíremse devido à pobreza que assolava aquele continente. Aqui eram muito bem cotadas e acabavam se tornando cafetinas.

De acordo com Armando Pereira ${ }^{5}$, estima-se que de 1908 a 1930, mais de 10000 pessoas desembarcaram em portos brasileiros com o fim de prostituição. $E$ não é muito diferente do que acontece hoje em dia, muitas mulheres eram enganadas ao se casarem com seus proxenetas para quebrarem as barreiras fiscais.

\footnotetext{
${ }^{5}$ Autor do Livro: Prostituição, uma visão Global, 1976.
} 
Naquela época, era pouco comum mulheres brasileiras serem traficadas. Uma ou outra era encontrada na Alemanha, Estados Unidos ou Nações do Prata. O comum era européias e vizinhas da América Latina serem encontradas nos bordéis brasileiros.

A partir de 1932, houve uma crescente valorização das brasileiras, o que aumentou a repressão ao tráfico, com exceção de algumas mulheres das "Troupes Artísticas" que de quando em quando viajavam para o Rio de Janeiro, São Paulo e Buenos Aires. Ainda assim o tráfico continuou, visto que era comum encontrar argentinas, uruguaias, paraguaias e chilenas nos bordéis. Essas vinham de forma legal e aqui se estabeleciam como prostitutas, passando-se por desapercebidas pelos policiais.

“...surge a prostituição-comércio, escapando embora à legislação fiscal, comercial e trabalhista, mas se revestindo, na clandestinidade, de todas as formas sociológicas inerentes à sua natureza de negócio. Haja vista que o fenômeno prostituição de súbito passa a envolver a existência de bolsas clandestinas de trabalho, acordos locais sobre tarifas reguladoras dos contatos sexuais, grupos operacionais dirigindo as migrações, especulações em torno da lei básica da oferta e da procura, a qual determina e orienta o fluxo de meretrizes para os mais rendosos mercados de trabalho".

Armando Pereira

Mesmo com a intensificação do combate ao tráfico e a conseqüente diminuição do fluxo dessas mulheres, a filosofia de que a "a prostituição é um mal necessário" acarretou um controle com autorização do poder público. A luta agora era outra: contra a autorização do poder público.

Com os vários Acordos e Convenções firmados no início da década de 19 pela extinta Liga das Nações, liquidou-se o abuso e a América do Sul deixou de receber as francesas. Essas prostitutas, até então nunca encaradas como supostas vítimas de uma situação, viajavam para outros países onde as fronteiras ainda eram vulneráveis como o Norte da África e Ásia Menor. Nesses países, se estabeleciam como escravas brancas.

No Brasil, o tráfico de mulheres brancas diminuiu, mas o tráfico interno entra em ebulição. As companhias de balés crescem com as falsas promessas dessas mulheres se tornarem artistas famosas. Elas são aliciadas e levadas a casas de cabarés de prostituição.

Todos esses dados, e principalmente o último parágrafo, citado por Armando Pereira em sua obra "Prostituição, uma visão Global" nos remete a uma realidade muito recente do tráfico de mulheres, onde são enganadas com falsas promessas de emprego, sucesso e bons salários no exterior, levando-nos a refletir o porquê de só agora buscar o enfrentamento desse problema, se há tanto nos assola com as mesmas características, com vítimas e histórias de vida tão parecidas. 
Naquele momento, não se tinha idéia da proporção tomada pelo Tráfico Interno de mulheres e somente uma ação do Governo Federal seria capaz de combater aquele mal que ia totalmente contra todos os "valores" da sociedade, porém ainda se faziam essenciais visto a necessidade de saciamento da libido masculino, haja vista serem essas as mulheres capazes de realizarem fantasias e desejos até então nunca pensadas em fazê-las com as esposas.

A realidade do tráfico de pessoas mudou: a incidência do crime aumentou, porém agora temos um ponto a nosso favor: a criminalização do tráfico. O fato de agora termos uma legislação que, mesmo não muito eficiente, nos proteja, nos faz ter mais força para combater esse crime e lutar pelo resgate dos direitos humanos dessas pessoas que se viram desamparadas, quando se depararam com a realidade que as esperava com pessoas que as enganaram e em um país diferente.

De acordo com João Henrique Ribeiro Roriz ${ }^{6}$, mesmo sabendo que a maioria das mulheres aliciada tem consciência que irão para o exterior exercer a prostituição, essas não sabem, entretanto, é que chegando no destino terá o seu passaporte e bilhete de passagem confiscados pelo proprietário e/ou gerente do prostíbulo e aí, permanecerá vigiada por um longo período até que consiga se livrar da pseudo-.

Por mais que essas vítimas, em sua maioria, saibam, pelo menos em parte, do futuro que as espera, é importante ressaltar que são vítimas duas vezes: vítimas do tráfico e vítimas sociais do país de origem, sendo este último o motivo que as empurram para o primeiro. O fato de a maioria das vítimas serem mulheres não é coincidência, mas essas também são as maiores vítimas de preconceito e discriminação. Essa marginalização acaba acarretando outros males, como o uso de drogas ilícitas, transmissão de doenças sexuais e Aids, além de problemas de ordem psicológica. É um ciclo vicioso que acaba por destruir cada vez mais essas pessoas, agravando, inclusive, problemas de saúde pública.

Em relação à participação das mulheres no mercado de trabalho, além de uma jornada pela qual recebem parcos salários, elas assumiram novos papéis e obrigações no contexto da família: desempenhos de trabalho, da afetividade e de sua sexualidade (PESTRAF-2002). Pior que a situação das mulheres, só as mulheres negras que ocupam os empregos de menor status e baixa renda, como de empregadas domésticas.

De acordo com a OIT/PEA (1998), as mulheres encontram-se, em sua maioria, em subempregos e no setor informal da economia, possuindo até 4 anos de estudo.

\footnotetext{
${ }^{6}$ Consultor do escritório das Nações Unidas Contra Drogas e o Crime.
} 
Além dessa situação de discriminação contra a mulher, ainda existe um crescimento cada vez maior das famílias chefiadas por elas, o que contribui para feminilização da pobreza. Com os menores salários do mercado se vêem obrigadas a sustentarem a si e a seus filhos, o que contribui, cada vez mais, para uma busca por melhores condições de vida, vez que em seu país as possibilidades de estudo e profissionalização se encontram cada vez mais distantes de sua realidade.

Essa situação exposta caracteriza o quadro ideal para que essas mulheres acreditem nas promessas dos aliciadores de que receberão bons salários e condições de criarem seus filhos e abandonem suas famílias, se aventurando em países, principalmente, da Europa.

Segundo denúncia apresentada no $1^{\circ}$ Seminário Internacional sobre Tráfico de Seres Humanos, ocorrido em 2000, em Brasília, as brasileiras representam 15\% das mulheres que deixam a América Latina para trabalharem em prostíbulos e saunas no mundo inteiro,. De acordo com a Fundação Helsinque, há cerca de 75 mil mulheres brasileiras se prostituindo em países da Europa.

Lamentavelmente, essa realidade também está cada vez mais presente na vida de crianças e adolescentes, principalmente da periferia. São levadas a outros estados brasileiros para saciarem os desejos masculinos e servirem de objetos sexuais de exploradores/criminosos. De acordo com a PESTRAF 2002, a faixa etária de maior incidência dentre as adolescentes é de 15 a 17 anos e dentre as mulheres é de 22 a 24 anos, ressaltando que, em sua maioria, são solteiras e com filho para cuidar.

Sobre as condições de vida das adolescentes, a maioria provém de municípios de baixo desenvolvimento socioeconômico, situados no interior do país ou nos bairros periféricos das grandes metrópoles, já sofreram algum tipo de violência intrafamiliar e extrafamiliar e as famílias apresentam quadros situacionais difíceis e vulneráveis frente à fragilidade das redes protetoras. ${ }^{7}$

Diante desse quadro, fica claro a necessidade de atuação mais eficaz por parte do Estado e da sociedade civil. Se as causas dessa evasão estão nas más condições de vida e de expectativa da população, porque não combater esses índices e, conseqüentemente, diminuir as estatísticas do tráfico de pessoas?

Em 2006, o Governo Lula, em resposta às demandas da sociedade, dos órgãos públicos e da imprensa, instituiu um Grupo de trabalho Interministerial com o objetivo de

\footnotetext{
${ }^{7}$ Fonte: LEAL, Maria Lúcia Pinto e LEAL, Maria de Fátima Pinto. Tráfico de Mulheres, crianças e adolescentes para fins de exploração sexual comercial: Um fenômeno Transnacional.
} 
elaborar proposta do Plano Nacional de Enfrentamento ao Tráfico de Pessoas. Juntamente com esse Grupo, veio a Política Nacional de Enfrentamento ao tráfico de Pessoas, onde foram previstas medidas eficientes para a extinção do tráfico de pessoas no país, além de preparar o caminho para a elaboração e implantação do Plano Nacional.

Essa Política surgiu em decorrência da publicação da PESTRAF 2002, que veio a se tornar referência no campo do tráfico e exploração comercial de pessoas, servindo de "ponto de partida" aos demais estudos que se seguiram, inclusive para a implantação de políticas públicas de enfrentamento ao crime.

Ao final de seu estudo, a PESTRAF listou algumas recomendações que, de acordo com a pesquisa, seriam necessárias para a superação desta questão social, a partir das quais estarão sendo analisadas as principais ações do Estado, no período de 2002 a 2007, no enfrentamento ao tráfico de pessoas para fins de exploração sexual no Brasil. 


\section{Ações de Enfrentamento ao Tráfico: resposta do Estado às recomendações da PESTRAF}

Diante do crescimento assustador do crime de tráfico de pessoas no Brasil e após a Publicação da PESTRAF, o Estado não podia ficar fora dessa luta e fingir que nada estava acontecendo. A repercussão da pesquisa e, principalmente, dos dados nela contidos, foi muito grande e algo precisaria ser feito para prestar satisfação àquelas vítimas, às suas famílias, às possíveis vítimas e a todos aqueles que, de alguma forma, conheceram o conteúdo do estudo. A sociedade precisava de resposta.

O Governo brasileiro se mobilizou e vem tomando uma série de medidas contra o tráfico. Além da ratificação do Protocolo para prevenir, suprimir e punir o tráfico de pessoas, especialmente mulheres e crianças, em suplemento à convenção das Nações Unidas contra o crime organizado transnacional, muita coisa ainda precisava ser feito para que esse acordo se fizesse valer, e são exatamente algumas dessas ações que se fazem objetos de estudo e serão analisadas no próximo capítulo.

\section{1 - ESTUDOS, PESQUISAS e CPMI}

Diagnóstico sobre Tráfico de Seres Humanos em São Paulo, Rio de Janeiro, Goiás e Ceará.

"Realização de estudos e de diagnósticos, considerando as múltiplas dimensões do fenômeno (política, social, econômica, jurídica e sociocultural), ampliando a compreensão sobre a violência estrutural e privilegiando os recortes de classe, gênero, etnia e idade".

Recomendação da PESTRAF, 2002.

Em 2004, o Pesquisador Marcos Colares ${ }^{8}$ realizou um levantamento de todos os Inquéritos e processos em andamento entre 2000 e 2003 sobre tráfico de pessoas nos estados de Goiás, Rio de Janeiro, Ceará e São Paulo cedidos pela Polícia Federal e pela Receita Federal.

A pesquisa teve como objetivo identificar os perfis das vítimas para fins de exploração sexual realizado no Brasil, identificando os destinos das vítimas do tráfico no Brasil, as nacionalidades dos traficantes e suas profissões, mapeando as conexões entre as atividades de turismo e o tráfico internacional de pessoas, inferindo sobre a presença de

\footnotetext{
${ }^{8}$ Advogado e Professor da Universidade Federal do Ceará.
} 
outros atores sociais na condição de vítimas e indicando as ações a serem empreendidas ou fortalecidas como formas de prevenção e combate ao tráfico de pessoas, pelo Estado, Organizações da Sociedade Civil e cidadãos em geral.

A escolha da realização a pesquisa nesses estados dá-se por diferentes razões. São Paulo e Rio de Janeiro foram escolhidos por serem consideradas, de acordo com essa pesquisa, as principais "portas de saídas" das vítimas do tráfico internacional, onde é "canalizado" o tráfico de outros estados brasileiros.

Goiás foi escolhido por sua fama de ser considerado o estado mais "freqüentemente envolvido em casos de tráfico de pessoas", além disso, um dos fatores determinantes para a inclusão de Goiás é a sua posição e inter-relação com as demais cidades do entorno ${ }^{9}$ do Distrito Federal.

A inclusão do Ceará neste levantamento é motivo de discussão e questionamento, pois o Ceará não se encontra dentre aqueles estados com maior incidência do crime de tráfico. O diferencial deste estado deve-se, de acordo com o autor, à grande migração de mulheres e adolescentes do interior para a Capital Fortaleza, em busca de emprego no crescente mercado do Turismo Sexual ${ }^{10}$.

O diagnóstico foi realizado por meio de questionários, os quais foram preenchidos com os dados da vítima, do indiciado e do fato ocorrido. A partir desses dados, pôde ser constatado aumento substancial no número de casos quando comparados o primeiro (2000) e o último ano (2003) investigados.

De acordo com a pesquisa, apenas $30 \%$ dos casos estudados resultam de investigação policial, os outros $70 \%$, de denúncias anônimas ou depoimentos das vítimas ou parentes, e dos 36 casos abordados, apenas 1(um) caso envolve vítima do sexo masculino. A maioria das vítimas tem idade entre 18 e 21 anos e quase $70 \%$ solteiras.

Quanto ao perfil dos indiciados, são predominantemente homens com mais de 30 anos, com família constituída, auto-intitulados empresários dos ramos que variam desde Agências de Turismo ou Modelos até Cassinos, e uma maior incidência de réus com nível médio e superior. Nesse último caso, deve ser levado em consideração o fato de que foram registrados mais de 40 policiais federais envolvidos, o que contribui para a elevação desse

\footnotetext{
${ }^{9}$ Conjunto de cidades do estado de Goiás que formam um cinturão em torno de Brasília, e concentram pobreza e alto índice de problemas de segurança pública.

${ }^{10}$ Este termo tem servido de debates com especialistas na área que defende mudança na nomenclatura por acreditaram que turismo não envolve exploração sexual, mas diversão saudável.
} 
grau de escolaridade, haja vista ser exigido qualificação superior para o cargo de policial federal.

Quase a totalidade dos indiciados é de nacionalidade brasileira, embora financiados por estrangeiros ${ }^{11}$.

A pesquisa chegou a várias outras conclusões que de alguma forma podem vir a contribuir na construção de políticas públicas no atendimento às vítimas e no combate ao crime, tornando-se possível, inclusive, detectar e punir os aliciadores, tendo em vista a possibilidade de, a partir das características de seu perfil, melhor identificá-los e impedir sua ação.

É necessário agir sempre com muita cautela quando o assunto é um Perfil a ser estabelecido, impedindo-se, assim, a construção de estereótipos, como é comum acontecer com prostitutas, por exemplo. Como é um mercado ilegal que está cada vez mais em alta, essas características tendem a se modificar ao longo do tempo, tornando-se mais eficaz trabalhar com dados gerais, sem características pré-determinadas, evitando-se, assim, o crescimento de preconceitos contra determinada classe ou perfil de pessoas.

\begin{tabular}{|l|l|}
\hline Pontos Fortes & Pontos Fracos \\
\hline A existência desse diagnóstico. & $\begin{array}{l}\text { Restringiu-se apenas a } 4 \text { estados } \\
\text { brasileiros. }\end{array}$ \\
\hline $\begin{array}{l}\text { Propõe algumas atitudes que o Estado } \\
\text { deveria tomar com vistas ao enfrentamento dados na construção do perfil das } \\
\text { da pobreza. }\end{array}$ & $\begin{array}{l}\text { vímas, como bem citaram os pesquisa- } \\
\text { dores, foram omitidos, devido à falta de } \\
\text { "cuidados" por parte dos entrevistadores no } \\
\text { Realizado em estados estratégicos no } \\
\text { preenchimento dos campos. } \\
\text { crime de TSH }\end{array}$ \\
\hline
\end{tabular}

\section{Indícios de Tráfico de Pessoas no universo de deportadas e não admitidas que ingressam no Brasil via o aeroporto de Guarulhos}

"Realização de estudos e diagnósticos, considerando as múltiplas dimensões do fenômeno (política, social, econômica, jurídica e sociocultural), ampliando a compreensão sobre a violência estrutural e privilegiando os recortes de classe, gênero, etnia e idade".

Recomendação da PESTRAF

\footnotetext{
${ }^{11}$ Dado referente à pesquisa em questão.
} 
Entre os meses de março e abril de 2005 foi realizada, no aeroporto internacional de Guarulhos, em São Paulo, pesquisa que teve como objetivo detectar a presença de brasileiras deportadas envolvidas no tráfico internacional de pessoa com fins de exploração sexual e, a partir daí, traçar um perfil socioeconômico das integrantes daquele universo e apreender os motivos que as levaram a viajar. Essas pessoas foram selecionadas dentre aquelas que desembarcavam de vôos provenientes da Europa. A metodologia utilizada foi aplicação de questionários e realização de entrevistas qualitativas.

Durante esses dois meses os pesquisadores ${ }^{12}$ se dividiram em duplas, em dois turnos, e com a ajuda de vários órgãos que trabalham diuturnamente no aeroporto e lidam diretamente com essas pessoas, como foi o caso da Infraero e do Departamento de Polícia Federal que contribuíram no fornecimento de informações necessárias, assim como no acesso às áreas onde se encontravam os passageiros que chegavam. A ASBRAD em muito colaborou para a aproximação e confiança dos entrevistados, pois a Associação oferecia ajuda àquelas que chegavam nessas condições.

A ANVISA cedeu uma sala no aeroporto, nos últimos dias de entrevistas, o que, de acordo com os pesquisadores, contribuiu significativamente para a realização da pesquisa.

Durante esses dois meses, 226 pessoas foram abordadas, dessas, 175 responderam ao questionário fechado, com média de 13 minutos cada, ou seja, 22,6\% se recusaram a responder o questionário. Pelo fato de vários entrevistados não o terem respondido por completo, a margem de erro para alguns percentuais foi superior a $39 \%$, fato que deve ser levado em consideração na avaliação e leitura das conclusões chegadas pela pesquisa.

"Essa situação de chegada de um grupo é complicada para a aplicação do questionário por algo que tem a ver com o compartilhamento de experiências profundas, que criam laços sociais. Observei que os grupos (que chegam) interagem de forma unida, tratam-se pelos primeiros nomes ou apelidos $e$ apenas poucos indivíduos se conheciam antes desta experiência. A aplicação do questionário fica dificultada, pois é difícil isolar um pouco alguma mulher. Elas respondem do mesmo modo nas duas situações (a sós ou em grupo)".

Diego -Pesquisador

Os pesquisadores se utilizaram de um Diário de Campo onde relataram suas experiências e conclusões pessoais, como é o caso da citação que acabamos de reproduzir.

\footnotetext{
12 Diego Romano, Paula Barros, Erêndida Simões, Carly Haka, Mariana Kruchim, Tali Almeida, Eron Almeida e Natália Bouças.
} 
Como pôde ser percebido através da reflexão do pesquisador Diego, o uso de questionários nem sempre é a melhor saída nessas situações de vulnerabilidade dos pesquisados.

Insistir no uso deste instrumento, em determinadas situações, pode incidir na perda de muitas informações da pesquisa, ou mesmo concluir fatos que não refletem a realidade. O fato é que, muitas vezes, chegamos ao campo de pesquisa já com uma meta a ser alcançada, quando na verdade deveríamos procurar coletar o maior número possível de informações e, a partir daí, chegarmos à conclusão dos fatos, sem antes premeditarmos o que vamos encontrar.

Dentre as várias conclusões a que chegaram os pesquisadores, Portugal seria o país que mais devolveu ou inadmitiu a entrada de brasileiras no país. No caso de deportadas, a liderança é da Itália, responsável por 24\% das deportações noticiadas no período, naquele aeroporto.

Outro aspecto que ficou claro na leitura da pesquisa é que os pesquisadores, mesmo sem entrevistar todas as deportadas ou inadmitidas, utilizam-se do seu "sensocomum" para chegarem a conclusões sem muito fundamento, de forma irresponsável, como é o caso daquelas mulheres que por estarem bem vestidas e não se enquadrarem naqueles estereótipos de prostitutas, que são pré-classificadas como aliciadoras.

"Tive uma recusa hoje. Uma mulher de mais ou menos 35 anos, séria, nada simpática veio deportada de Madri. Estava com o orgulho ferido. Era a única deportada do vôo e disse ter passagem livre na Espanha. Idas e vindas somam em torno de cinco viagens para o país. -não quero responder nada- $e$ saiu de perto. Mas sua resposta não foi dada na boa. Eu e (integrante da ASBRAD) percebemos que havia algo muito estranho naquela mulher. Ela logo lançou:- para mim, essa daí é aliciadora!- será??? Não consegui desvendar o mistério".

Carly - Pesquisadora

De acordo com pesquisa, 92,6\% dos deportados se autoclassificam mulheres, $5,1 \%$ homens e $2,3 \%$ transgêneros. Cerca de $40 \%$ dos entrevistados, que admitiram terem se envolvido na indústria do sexo, são transgêneros. 47,4\% estão entre 25 e 40 anos e $37,1 \%$ estão entre 18 e 24 anos.

Goiás, Minas Gerais e Paraná representam mais da metade dos estados de origem das não admitidas. Dentre as deportadas, os principais estados são Goiás, Paraná e São Paulo, com cerca de 50\%.

Surpreendentemente, quase $20 \%$ das entrevistadas declararam possuir nível superior completo ou incompleto, registrando-se um caso, inclusive, de pós-graduação e 
apenas 22,9\% apresentaram possuir até o nível fundamental, o que contraria os dados do Ministério da Justiça quando declara que apenas 3\% das vítimas chegaram ao nível superior $^{13}$. Porém, vale ressaltar que os dados do Ministério da Justiça estão relacionados às vítimas em potencial, quando os dados da Pesquisa em questão são relacionados às pessoas entrevistadas, podendo ser vítimas, aliciadores ou não se enquadrando em nenhuma dessas duas categorias.

Outra conclusão que a pesquisa chegou foi que $64 \%$ das pessoas entrevistadas se declararam católicas e $22,9 \%$ evangélicas que, em boa parte dizem terem sido convidadas para trabalharem em igrejas européias, porém, dentre as que afirmaram fazerem parte da indústria do sexo, todas são católicas, com exceção de uma que se declarou sem religião.

Em que pode colaborar um dado como esse é uma questão difícil de responder. Será que a religão seria uma determinante no êxodo de mulheres para a Europa com esse fim?

A Pesquisa em estudo, como já foi deixado claro, destinou-se a concluir dados qualitativos, com entrevistas, e quantitativos, por meio de aplicação de questionários. Foi possível diagnosticar pontos que levantam suspeitas quanto à credibilidade ou mesmo utilidade de uma pesquisa como essa, uma vez que os dados não podem ser muito confiáveis, pois os próprios pesquisadores admitem que, devido ao pouco número de questionários respondidos por completo, "os resultados devem ser analisadas com ressalvas e devem ser considerados como elementos que indicam tendências a serem analisadas em eventuais novas análises mais pormenorizadas".

Além disso, os dados e conclusões a que os pesquisadores chegam não diferem muito de outras pesquisas já publicadas, no que diz respeito, principalmente, aos perfis das supostas vítimas do tráfico de pessoas com fins à exploração sexual.

A neutralidade, elemento essencial para o bom êxito das pesquisas realizadas, muitas vezes se mostrou distante daquele campo de pesquisa, o que pode ter vindo a prejudicar as conclusões.

Hoje, o Aeroporto de Guarulhos, através do Ministério da Justiça, oferece atendimento às vítimas do Tráfico que desembarcam no aeroporto, além de cursos de capacitação aos profissionais envolvidos, inclusive funcionários das empresas aéreas, ensinando-os como identificar e agir com essas pessoas.

\footnotetext{
${ }^{13}$ Dados retirados do site do Ministério da Justiça
} 


\begin{tabular}{|l|l|}
\hline Pontos Fortes & Pontos fracos \\
\hline $\begin{array}{l}\text { A própria existência de uma pesquisa como } \\
\text { essa. }\end{array}$ & $\begin{array}{l}\text { Utilização de questionário. Instrumento } \\
\text { muitas vezes "traiçoeiro" em determinadas } \\
\text { situações. }\end{array}$ \\
\hline $\begin{array}{l}\text { Alertou quanto à existência do preconceito } \\
\text { e maus tratos contra brasileiras em outros } \\
\text { países. }\end{array}$ & $\begin{array}{l}\text { Baixa adesão nas respostas do } \\
\text { questionário, o que aumentou em muito a } \\
\text { margem de erro da pesquisa. }\end{array}$ \\
\hline $\begin{array}{l}\text { Colocou o tema em evidência, o que } \\
\text { contribui para o enfrentamento à questão do } \\
\text { tráfico. }\end{array}$ & $\begin{array}{l}\text { Um universo muito pequeno de } \\
\text { entrevistadas para se traçar um } \\
\text { estudo/perfil sobre o tema. }\end{array}$ \\
\hline $\begin{array}{l}\text { Através da pesquisa, foi possível implantar } \\
\text { um Posto de Atendimento à vitima no }\end{array}$ & $\begin{array}{l}\text { Não se sabe ao certo se as histórias são } \\
\text { verdadeiras. }\end{array}$ \\
\cline { 2 - 2 } aeroporto. & Pessoas com o estado emocional abalado. \\
\cline { 2 - 2 } & $\begin{array}{l}\text { Não acrescentou muita coisa, além de } \\
\text { informações já conhecidas por outras } \\
\text { fontes. }\end{array}$ \\
\hline
\end{tabular}

\section{O Tráfico de Seres Humanos no Estado do Rio Grande do Sul}

"Realização de estudos e de diagnósticos, considerando as múltiplas dimensões do fenômeno (política, social, econômica, jurídica e sociocultural), ampliando a compreensão sobre a violência estrutural e privilegiando os recortes de classe, gênero, etnia e idade".

Recomendação da PESTRAF,2002.

No ano de 2005, o Ministério da Justiça, juntamente com o UNODC ${ }^{14}$ e o Governo do Estado do Rio Grande do Sul, realizaram naquele Estado um estudo baseado em inquéritos policiais instaurados entre 1996 e 2004 e notícias veiculadas pela mídia impressa no estado no mesmo período, com o objetivo de caracterizar o Tráfico de Pessoas para fins de exploração sexual comercial no estado.

Essa Pesquisa, assim como as demais aqui apresentadas, teve como ponto de partida a PESTRAF, por meio da qual várias rotas foram identificadas dentro do Estado gaúcho, o que impulsionou a elaboração deste estudo. A sua vulnerabilidade dá-se, em especial, pela sua localização fronteiriça com outros países da América Latina, o que contribui para uma maior incidência do crime e, conseqüentemente, tratamento diferenciado para a região.

\footnotetext{
${ }^{14}$ Escritório das Nações Unidas Contra Drogas e Crimes.
} 
A construção da pesquisa foi importante a partir do momento em que, mediante análise do número de inquéritos policiais instaurados, foi possível identificar cidades com maior registro de casos de tráfico, tornando-se viável a elaboração de políticas públicas para as regiões mais afetadas, levando-se em consideração as características específicas e culturais de cada uma dessas cidades.

Outro fator positivo na formulação desse diagnóstico é a sensibilização provocada na sociedade em geral, como também nas autoridades municipais, estaduais e federais, trazendo à tona um problema de ordens política, social e econômica que, muitas vezes, estava encoberto. Realidades como a exploração e comercialização sexual de crianças e adolescentes são encaradas com muita naturalidade por uma grande parte das pessoas, das quais, muitas vezes, fazem parte autoridades pagas pelo Estado para combater esses absurdos.

A partir do momento que o Estado, a Sociedade Civil e a Mídia se sensibilizam para desnaturalizar essas práticas, torna-se possível um combate mais forte e eficaz, levando as pessoas a pensarem qual o futuro dessas mulheres, crianças e adolescestes, ou até mesmo homens, que se vêem comercializados como objetos e que servem unicamente para proporcionar um prazer mórbido a homens desprovidos de caráter e mínimos valores éticos e morais.

A pesquisa, coordenada por Jacqueline Silva ${ }^{15}$, traçou um perfil, se é que existe, dos aliciadores presos durante o período abordado pela pesquisa e, não muito diferente do que era esperado, a maioria é do sexo masculino e proveniente de países vizinhos da América do Sul, principalmente Argentina e Paraguai.

Também foi constatada a grande sensibilização por parte de profissionais da rede pública de saúde e das ONG's, o que, de acordo com a pesquisa, proporciona um campo fértil para políticas públicas mais eficientes.

Concluindo, a pesquisa lembra as peculiaridades do crime no Rio Grande do Sul. Uma dessas peculiaridades é o fato de que no referido estado, o maior fluxo de migrações é feito por rodovias, dada a proximidade e facilidade de acesso aos países do Mercosul, e de que cidades como Caxias do Sul, $1^{\circ}$ lugar no DIEESE, equivalente estadual ao índice de desenvolvimento humano da ONU, também se encontram na rota do tráfico.

\footnotetext{
${ }^{15}$ Graduada em Serviço Social e mestre e doutora em educação.
} 


\begin{tabular}{|l|l|}
\hline Pontos Fortes & Ponto Fraco \\
\hline $\begin{array}{l}\text { Realizado em um estado estratégico devido } \\
\text { à grande atuação do crime na região } \\
\text { fronteiriça. }\end{array}$ & $\begin{array}{l}\text { Não trouxe muitas informações novas } \\
\text { quanto aos perfis dos envolvidos. Trouxe } \\
\text { aquilo que já era sabido de outros estudos. }\end{array}$ \\
\cline { 1 - 1 } $\begin{array}{l}\text { Apontou as principais cidades da rota do } \\
\text { tráfico no estado, o que contribui na } \\
\text { formulação de políticas públicas para a área }\end{array}$ & \\
\cline { 1 - 1 } $\begin{array}{l}\text { Serve para sensibilização e fonte de } \\
\text { pesquisa para o tema }\end{array}$ & \\
\hline
\end{tabular}

\section{CPMI da Exploração Sexual de Crianças e Adolescentes}

"Investigação detalhada de crimes relacionados ao tráfico: desaparecimento; seqüestro; adoção ilegal; prostituição infanto-juvenil; turismo sexual; tráfico de drogas; organizações criminosas; e economias clandestinas".

"Ação efetiva dos órgãos de segurança e da justiça, no sentido de investigar e punir os casos de tráfico, investigando e punindo exemplarmente os casos de conivência e/ou participação de autoridades e membros das elites locais".

Recomendações da PESTRAF, 2002.

Durante aproximadamente um ano, o Congresso Nacional se dedicou a investigar as redes de exploração sexual de crianças e adolescentes por meio de uma CPMI. A Comissão foi instalada no dia 12 de junho de 2003 e seu relatório final foi entregue no final de junho do ano seguinte.

$\mathrm{Na}$ investigação, a CPMI percorreu 22 Estados, analisou 958 documentos, ouviu 285 pessoas e recebeu 832 denúncias vindas de todo o país, das quais 543 efetivaram-se em notícia-crime, além de 20 diligências e 34 reuniões e audiências públicas, nas quais foram ouvidos representantes da sociedade civil, vítimas, acusados e órgãos do poder público. Foram sugeridos cerca de 250 indiciamentos, dentre autoridades dos mais variados ramos de atuação.

Ficou constatada a existência de exploração sexual de crianças e adolescentes em todo o Brasil, seja em grandes cidades ou pequenos municípios nos mais distantes pontos do país. Como esse crime está tão disseminado? Por meio de redes de atuação nacional que reduzem meninos e meninas a meros objetos sexuais que servem, unicamente, para satisfazerem prazeres sexuais de homens que se igualam a animais irracionais quando agem de forma indiscriminada, instintivamente.

Ao contrário do que se acredita no "senso comum", a complexidade desse fenômeno não está relacionada apenas à pobreza e à miséria, também a questões culturais 
como machismo e preconceito contra crianças e adolescentes. Muitos tendem a ver esse "menor" como mercadoria de uso.

A CPMI também constatou que, ao contrário do que se acreditava sobre o perfil do abusador/aliciador, já não existe um perfil, pois foi constatado o envolvimento, inclusive, de autoridades que seriam responsáveis por combater essa violência, defendendo os direitos dessas crianças e adolescentes, como é o caso de policiais, juízes, políticos e líderes religiosos, dentre outras autoridades.

Além dos prejuízos físicos causados a essas crianças, existem fatores muito mais graves e prejudiciais que vão muito além de meras marcas que cicatrizam e desaparecem com o tempo. Essas crianças acabam perdendo a referência dos papéis desempenhados pelos membros da família, pois muitas delas utilizam o dinheiro da prostituição para colocarem comida dentro de casa. ${ }^{16}$

A exclusão social é, mais uma vez, preponderante quando o assunto é perspectiva de futuro para esses excluídos que, sem direito de escolha se viram nesse mundo cruel da exploração sexual infanto-juvenil.

A CPMI propôs mudanças principalmente na legislação, tanto no ECA quanto no Código Penal. Essas mudanças, como pôde ser constatado em 2005 com as alterações do Código Penal, foram, na sua maioria, ouvidas e atendidas. Porém de nada valerá essas mudanças nas Leis se os acusados não responderem e forem punidos pelas suas atitudes.

De acordo com Fernanda Sucupira ${ }^{17}(2006)$, "As ações de prevenção e de atendimento psicossocial às vítimas são fundamentais, mas a ausência de punição aos responsáveis por esses crimes também consiste num dos principais entraves ao enfrentamento desse tipo de violações dos direitos de crianças e adolescentes. A certeza da impunidade perpetua a violência sexual, e a absolvição em si dá mais força ao agressor, que se sente livre para continuar cometendo esses crimes, além de gerar danos secundários nas vítimas e em seus familiares". ${ }^{18}$

Foi um ano de muita investigação sob a presidência da Deputada Patrícia Saboya, tendo como relatora a também Deputada Maria do Rosário, onde o tema foi colocado em evidência e serviu para mobilizar a sociedade e as autoridades públicas. Finalizam o relatório, crendo que algo de bom foi plantado, na esperança de que os direitos

\footnotetext{
${ }^{16}$ Fonte: www.senado.gov.br/web/senador/patriciasaboyagomes/ca/cpmi/oquee.htm. Acesso em maio/2007.

17 Jornalista da Agência Carta Maior.

${ }^{18}$ Fonte: Impunidade é um dos grandes vilões no enfrentamento à violência sexual, em www.girassolidario.org.br. 27/11/2006.
} 
previstos na Constituição Federal e do Estatuto da Criança e do Adolescente sejam aplicados.

"Este relatório apresenta à população a síntese do nosso trabalho. Desejamos que sirva de instrumento para fortalecer as ações cotidianas das autoridades, dos órgãos públicos e da sociedade organizada que trabalha incansavelmente para ver na prática serem traduzidos os direitos das crianças e dos adolescentes inculpidos na Constituição Federal e especialmente no Estatuto da Criança e do Adolescente". ${ }^{19}$

\begin{tabular}{|l|l|}
\hline Pontos Fortes & Ponto Fraco \\
\hline $\begin{array}{l}\text { A própria existência de uma CPMI sobre o } \\
\text { assunto. }\end{array}$ & Impunidade dos acusados. \\
\hline $\begin{array}{l}\text { Nas audiências foram ouvidas } \\
\text { representantes da sociedade civil, vítimas, } \\
\text { acusados e órgãos do poder público. }\end{array}$ & \\
\hline $\begin{array}{l}\text { Lista de recomendações ao governo sobre } \\
\text { educação, cultura, esporte e modificações } \\
\text { nas legislações, inclusive referente ao } \\
\text { Tráfico de Pessoas. }\end{array}$ & \\
\hline $\begin{array}{l}\text { Mais de } 250 \text { pessoas indiciadas, dentre } \\
\text { autoridades dos diversos ramos do poder. }\end{array}$ & \\
\hline
\end{tabular}

\section{2 - CAPACITAÇÃO}

\section{Manual - Tráfico de Pessoas Para Fins de Exploração Sexual}

"Sensibilização, mobilização e capacitação das pessoas que atuam no sistema de atendimento e nos espaços de defesa e de responsabilização".

"Treinamento dos Conselheiros Tutelares e dos profissionais das Delegacias especializadas, priorizando a visibilidade, o entendimento e o combate ao fenômeno".

Recomendações da PESTRAF, 2002.

No ano de 2005, surgiu o primeiro Curso Virtual de Capacitação à Distância no Departamento de Polícia Federal. O curso foi voltado para o tráfico de pessoas para fins de exploração sexual e tinha como objetivo fornecer informações para colaborar com aqueles a quem cabe a tarefa de investigar, prender, acusar e julgar os traficantes, fornecendo informações que possam servir de auxílio desde a descrição do modus operandi dos traficantes, estimativas sobre o número global de vítimas e os métodos mais adequados

\footnotetext{
${ }^{19}$ Fonte: Síntese do Relatório da CPMI da exploração sexual de crianças e adolescentes.
} 
para lidar com elas, até endereços e telefones de organizações assistenciais, embaixadas de países estrangeiros e de consulados brasileiros nos principais locais de ação dos criminosos.

Desse curso, derivou-se um Manual amplamente divulgado no meio policial, de uso prático e de fácil entendimento, com figuras e exemplos de vítimas do Tráfico de Pessoas.

Devido à dimensão e ao aumento no número de crimes de tráfico de pessoas, existe na Secretaria Nacional de Segurança Pública - SENASP uma solicitação de outro Curso de Capacitação virtual para os profissionais da área, em especial Policiais Federais. O curso terá como base, novamente, o Manual elaborado em 2005.

O fato de ser um curso virtual configura uma grande conquista para o enfrentamento do tráfico, uma vez que o alcance é infinitamente maior. Profissionais de todas as regiões do país estarão sendo treinados e informados ao mesmo tempo. Regiões de difícil acesso, como fronteiras e delegacias do extremo norte do país terão a oportunidade de fazerem parte da equipe de profissionais qualificados a combaterem o tráfico e a exploração sexual.

O pesquisador Marcelo Hazeu defende que "investir na formação e sensibilização dos operadores da justiça e segurança ainda se faz extremamente necessário". ${ }^{20}$ As palavras de Hazeu reafirmam a urgência em investir nesses profissionais que estão na "linha de frente" do combate. São, com certeza, os mais indicados a enfrentarem e vencerem essa luta, portanto façamos nossas "apostas" e deixemos de ignorar este mal que há tantos anos nos persegue.

\begin{tabular}{|l|l|}
\hline Pontos Fortes & Pontos Fracos \\
\hline Criação do Manual & \\
\hline $\begin{array}{l}\text { Destinado àqueles a quem cabe investigar, } \\
\text { prender, acusar e prender. }\end{array}$ & \\
\hline $\begin{array}{l}\text { Didático, com exemplos de fácil } \\
\text { entendimento. }\end{array}$ & \\
\hline $\begin{array}{l}\text { Mostra desde "O que é tráfico", passando } \\
\text { por dados estatísticos, até telefones de } \\
\text { embaixadas no Brasil e no exterior. }\end{array}$ & \\
\hline $\begin{array}{l}\text { Utilizado como base para a formulação do } \\
\text { primeiro curso virtual à distância do DPF. }\end{array}$ & \\
\hline
\end{tabular}

${ }^{20}$ Trecho da pesquisa Tráfico de Mulheres, Crianças e adolescentes para Fins de Exploração Sexual na Amazônia. 


\title{
3.3 - INSTRUMENTOS LEGAIS E POLÍTICOS
}

\author{
Alteração do Código Penal Brasileiro \\ "Reforçar, no plano jurídico, os referenciais de combate ao tráfico, tais como o Código Penal \\ Brasileiro...".
}

Recomendação da PESTRAF, 2002.

Se existia um ponto de contestação em comum entre todos aqueles que estavam envolvidos no enfrentamento do tráfico de pessoas era, com certeza, a necessidade de mudança no Código Penal Brasileiro no que diz respeito à tipificação do crime no artigo 231. O Código trazia apenas a mulher como possível vítima do tráfico, e essa mulher precisaria ser levada para outro país para se constituir crime. Assim era a redação anterior:

"Art. 231. Promover ou facilitar a entrada, no território nacional, de mulher que nele venha exercer a prostituição, ou a saída de mulher que vá exercê-la no estrangeiro":

Pena - reclusão de 3 a 8 anos.

Esta definição equivocada, além de ultrapassada é muito preconceituosa, pois enxerga apenas a mulher como provável vítima de uma violência que não mais discrimina sexo, idade ou condição social. O objetivo é apenas obter lucro.

Em entrevista ao Jornal do Brasil em 22/02/2004, Leila Paiva, do Ministério da Justiça, declarou que um dos grandes desafios era conseguir alterar a legislação brasileira. Precisava-se incluir os tráficos interestaduais e intermunicipais, reconhecer que os homens e meninos também são vítimas do tráfico (...).

Thaís Dumêt ${ }^{21}$ declara, também no ano de 2004, a um site ${ }^{22}$, que "a legislação é muito confusa e, no caso de tráfico de crianças, é mais confusa ainda. O citado artigo (231 $\mathrm{CP})$ trata apenas de tráfico de mulheres e não abrange homens nem meninos. Alguns artigos do $\mathrm{ECA}^{23}$ falam sobre o envio de crianças ao exterior (...) mas não especificam a finalidade, não falam em fins de exploração sexual. Observamos ainda que a pena para o tráfico de mulheres é mais grave do que mandar crianças para o exterior".

O enquadramento no crime de tráfico de mulheres (art. 231 Código Penal) pode ser feito em casos que, pela pesquisa, são denominados "tráfico de fronteiras" e "tráfico transnacional". O "tráfico interno" poderia ser enquadrado nos artigos que tratam de

\footnotetext{
${ }^{21}$ Coordenadora do Projeto de Combate ao Tráfico de pessoas na OIT.

${ }^{22} \mathrm{O}$ site em referência é o www.caminhos.ufms.br.

${ }^{23}$ Estatuto da Criança e do Adolescente.
} 
mediação para servir a lascívia de outrem (art. 227 CP), Favorecimento da prostituição (art. 228 CP), Casa de prostituição (art. 229 CP) e Rufianismo (art. 230 CP), pois as várias fases do processo de tráfico (aliciamento ou recrutamento; deslocamento; recebimento e alojamento no contexto do mercado de sexo) carregam características desses crimes. ${ }^{24}$

Em 2005, pela Lei 11.106/2005, o artigo 231 do Código Penal sofre mudanças significativas: O antes denominado "Tráfico de mulheres", agora se classifica como "Tráfico internacional de pessoas". Além disso, também passa a ser previsto no Código Penal o "Tráfico interno de pessoas", no art. 231-A. A nova redação do Código Penal é:

"Art. 231. Promover, intermediar ou facilitar a entrada, no território nacional, de pessoa que venha exercer a prostituição ou a saída de pessoa para exercê-la no estrangeiro".

Pena - reclusão de 3 a 8 anos e multa.

$\S 1^{\circ}$. Se ocorre qualquer das hipóteses do $\$ 1^{\circ}$ do art. $227^{25}$ :

Pena - Reclusão de 4 a 10 anos;

$\S 2^{\circ}$ Se há emprego de violência, grave ameaça ou fraude, a pena é de reclusão de 5 a 12 anos e multa, além da pena correspondente à violência"

Com a nova redação, foi mantida a pena de reclusão no mesmo patamar, contudo deverá ser aplicada cumulativamente com pena de multa, quando antes a multa só acontecia quando verificada a finalidade lucrativa. Para o legislador, atualmente, tal crime sempre será praticado com o fim de lucro.

Além da retirada do monopólio do sexo feminino em relação ao pólo passivo, agora qualquer pessoa poderá nele figurar. O Código também incluiu o verbo "intermediar", que amplia o alcance e abrange muitas condutas adotadas na prática do crime em questão, antes de difícil punibilidade devido à falta de previsibilidade na Lei. "Enquanto as condutas de promover ou facilitar têm alcance mais restrito, a intermediação completa o rol das condutas típicas que normalmente estão ligadas às infrações de tal natureza e permite não deixar descoberto; fora da esfera de proteção penal, razoável número de comportamentos que se ajustam ao verbo". ${ }^{26}$

Finalmente, o Código Penal foi modificado e se adequou à realidade brasileira, onde, para o crime, as barreiras do sexo, idade e condição social estão se tornando cada vez menos preponderantes. Apesar de sabermos que as maiores vítimas

\footnotetext{
${ }^{24}$ Trecho retirado da Pesquisa Tráfico de mulheres, crianças e adolescentes para fins de exploração sexual comercial na Amazônia, coordenado por Marcelo Hazeu - Pesquisador do Movimento República de Emaús.

${ }^{25}$ Art. 231, $\S 1^{\circ}$ do art. 227 - Se a vítima é maior de 14 (catorze) e menor de 18 (dezoito) anos, ou se o agente é seu ascendente, descendente, cônjuge ou companheiro, irmão, tutor ou curador ou pessoa a quem esteja confiada para fins de educação, de tratamento ou de guarda.

${ }^{26}$ Fonte: www.mundojuridico.adv.br/sis artigos.asp?codigo=148, por Renato Marcão
} 
ainda são as mulheres, o Tráfico de Pessoas, vem ganhando espaço e ampliando seus alvos. Homem e crianças passam a também serem cotados para fazerem parte, de forma cada vez mais atuante, do cruel e covarde mundo da exploração e do comércio sexual.

\begin{tabular}{|l|l|}
\hline Pontos Fortes & Pontos Fracos \\
\hline A Alteração de um Código tão antigo. & \\
\hline $\begin{array}{l}\text { Homens também passam a ser encarados } \\
\text { como possíveis vítimas do tráfico de pessoas. }\end{array}$ & \\
\hline $\begin{array}{l}\text { Manteve-se a mesma pena, porém com a } \\
\text { inclusão de multa em todos os casos, } \\
\text { acreditando-se que sempre existe o lucro. }\end{array}$ & \\
\hline Criminalizou-se o tráfico interno de pessoas & \\
\hline $\begin{array}{l}\text { Maior enquadramento de condutas } \\
\text { convergentes devido à mudança no caput do } \\
\text { artigo. Onde antes era Promover ou Facilitar, } \\
\text { agora é INTERMEDIAR. }\end{array}$ & \\
\hline
\end{tabular}

\section{Política Nacional de Enfrentamento ao Tráfico de Pessoas}

"Definição de um Plano Nacional, contendo as principais diretrizes de atuação frente ao fenômeno".

Recomendação da PESTRAF, 2002.

O Governo Federal, na pessoa do Excelentíssimo Senhor Presidente Luiz Inácio Lula da Silva, lançou, dia 27 de outubro de 2006, a Política Nacional de Enfrentamento ao Tráfico de Pessoas, o qual envolve 14 Órgãos Federais. Trabalho escravo e exploração sexual de crianças e adolescentes são os principais crimes a serem combatidos. O decreto $n^{0} 5.948$, de 26/10/06, traz diretrizes e princípios que deverão ser obedecidos no combate ao problema e servirá de parâmetro para a criação do Plano Nacional de Enfrentamento ao Tráfico de Pessoas.

A Política foi elaborada pela Secretaria Nacional de Justiça, Secretaria Especial de Políticas para as Mulheres e Secretaria Especial de Direitos Humanos, juntamente com Organizações da Sociedade Civil e outros órgãos do Governo que atuam na área. O Governo prevê o envolvimento, no total, de 14 órgãos, que farão parte do Grupo de Trabalho, publicado no Diário Oficial da União dia 14/03/2007, que elaborará o Plano Nacional responsável por detalhar ações, estabelecer metas, prazos e órgãos responsáveis pelo enfrentamento do Tráfico. 
De acordo com Cláudia Chagas ${ }^{27}$ o objetivo da Política é "combater o tráfico de pessoas de forma coordenada e sistemática, além de sensibilizar a sociedade brasileira sobre o tema". Cláudia ressalta ainda a necessidade de investir nos profissionais envolvidos na luta, permitindo que estejam mais habilitados para visualizar focos do tráfico e tratar de suas vítimas: "Entre outras ações, iremos capacitar profissionais de todas as esferas do governo federal para reconhecer os principais indícios do tráfico e, principalmente, oferecer auxílio às vítimas".

Para todos aqueles que trabalham no combate ao Tráfico de Seres Humanos, essa é, sem dúvida, a maior das conquistas até agora. De acordo com Neide Viana Castanha $^{28}$, "a importância do decreto é o seu impacto: ele traz um posicionamento do governo assumindo o problema, assumindo o tráfico de pessoas como política pública". Porém, mesmo concordando com a importância do Plano, Neide critica a proposta no atendimento às vítimas: "Não deve ser apenas atendimento psico-social e jurídico, que são importantes, mas desenvolvimento social e econômico".

A declaração da Secretária Geral do CECRIA deixa a entender que, mais importante que cuidar das vítimas do tráfico, é cuidar daquelas que ainda não são vítimas e impedir, por meio de políticas públicas de atendimento básico ${ }^{29}$, que essas entrem no mundo da exploração e comercialização sexual.

Em contrapartida, e em defesa do futuro Plano, Bárbara Campos ${ }^{30}$ comemora a maior participação de outros órgãos do governo: "Até agora, o tráfico de pessoas foi tratado no sentido da justiça, de combate ao crime organizado. A Política traz metas em educação, em trabalho, emprego", afirma.

De forma mais ampla, o Tráfico de Pessoas passa a ser encarado não apenas como um crime, no qual a Polícia Federal deve combater. Agora, com a elaboração dessa Política e formação desse Grupo de trabalho, o tráfico de pessoas passa a ser problema de todos e não apenas "caso de polícia". Estão envolvidos nesse Grupo, além do Ministério da Justiça, as Secretarias Especiais de Políticas para as Mulheres e de Promoção da Igualdade Racial e a Casa Civil da Presidência da República, o Ministério de Desenvolvimento Social e Combate à Fome, o Ministério da Saúde, o Ministério do Trabalho e Emprego, o Ministério do Desenvolvimento Agrário, o Ministério da Educação, o Ministério das Relações Exteriores,

\footnotetext{
${ }^{27}$ Na ocasião, Secretária Nacional de Justiça.

${ }^{28}$ Secretária Geral do Centro de Referência, Estudos e ações sobre crianças e adolescentes - Cecria.

29 Políticas do Governo voltadas ao atendimento das necessidades básicas do cidadão, como emprego, segurança, educação, saúde, saneamento básico, etc.

${ }_{30}$ Assessora da Secretaria Nacional de Justiça - SNJ.
} 
o Ministério do Turismo, o Ministério da Cultura, a Advocacia-Geral da União, o Ministério Público Federal e o Ministério Público do Trabalho.

Todos esses órgãos, juntos, assumem um papel muito importante, dentro de suas peculiaridades, como bem ressaltou Marina Oliveira ${ }^{31}$ : "As discussões começaram no final de 2005 e estudamos então uma ação conjunta que unisse os esforços de vários ministérios em uma só estratégia".

O envolvimento dos vários ramos de atuação permite que o tráfico seja combatido desde suas raízes. As causas que levam uma jovem a se interessar em sair de sua comunidade, de próximo de seus familiares para se aventurar em terra estranha precisam ser muito fortes, caso contrário tentaria levar sua vida, ainda que modesta, no seu próprio país. E são essas causas que trazem a maior dificuldade do enfrentamento ao tráfico de pessoas e por isso devem ser o foco de qualquer trabalho que se atreva a combatê-lo.

Políticas agrárias para o trabalhador rural, por exemplo, tendem a manter esse trabalhador no campo, impedindo-o de se tornar presa fácil nos subúrbios das grandes cidades. O Ministério da Educação pode atuar no fornecimento de uma boa Política de Educação, que proporcione, a todos, iguais condições de concorrerem no mercado de trabalho. O Ministério da Saúde pode, por meio de hospitais e profissionais de qualidade, proporcionar uma saúde comprometida com a qualidade no atendimento, sem a necessidade de que essa jovem tenha que procurar meios ilícitos ou desumanos para pagar uma consulta em hospital particular. E da mesma forma que esses, os demais Ministérios também têm seu papel junto à prevenção do Tráfico e exploração sexual que, sem bem desempenhado, permitirá que esses dados, que hoje fazem do Brasil um dos principais países de origem das vítimas do tráfico em todo mundo, façam parte do passado e o transforme em país modelo no combate e enfrentamento ao crime.

\footnotetext{
${ }^{31} \mathrm{Na}$ época era Gerente de projetos da SNJ. Hoje trabalha na UNODC.
} 


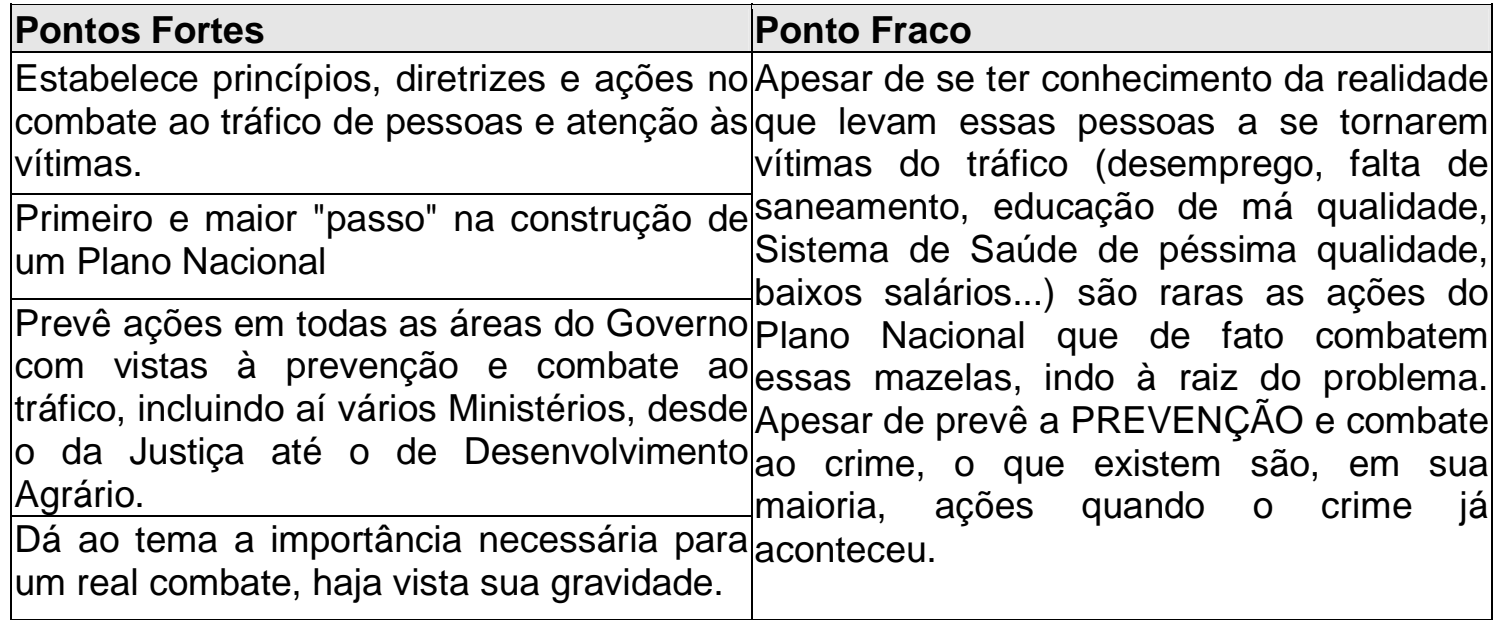

\section{Seminário Luso-Brasileiro sobre Tráfico de Pessoas e Imigração llegal}

"Estabelecimento de acordos diplomáticos internacionais, através de protocolos de intenções, entre os países que foram apontados nas rotas de tráfico, tencionando estabelecer ações conjuntas para combater o tráfico de mulheres, crianças e adolescentes para fins sexuais".

Recomendação da PESTRAF, 2002.

Fruto de um acordo de cooperação firmado em 2003 entre o Brasil e Portugal para Prevenção e Repressão do Tráfico Ilícito de Imigrantes, em 2005 os dois países acordaram sobre a realização de um Seminário sobre tráfico de pessoas e imigração ilegal, primeiramente em Portugal e em seguida no Brasil.

Conforme estabelecido, o I Seminário Luso-Brasileiro sobre Tráfico de Pessoas e Imigração llegal aconteceu entre os dias 22 e 24/05/2006 na cidade de Cascais, em Portugal.

A segunda etapa do I Seminário Luso-Brasileiro sobre Tráfico de Pessoas e Imigração Ilegal//rregular aconteceu, conforme previsto, no Brasil, na cidade de Brasília, no período de 27 a 29/11/2006. O Seminário teve como objetivo "aprofundar os atuais meios de cooperação entre a República Portuguesa e a República Federativa do Brasil no âmbito dos serviços competentes, preconizando medidas concretas ao nível dos mecanismos que previnam e combatam o tráfico de pessoas, bem como das redes criminosas que violam os direitos dos migrantes". 
Após esses Encontros, os dois governos firmaram duas declarações ${ }^{32}$ conjuntamente, onde se comprometem a aprofundarem as pesquisas na área.

De acordo com o Relatório de Gestão da Secretaria Nacional de Justiça, o objetivo principal dos trabalhos ocorridos nas duas cidades é "sinalizar de forma clara quem são as vítimas para atendê-las de maneira diferenciada, como sugere a normativa internacional, evitando que a bandeira do enfrentamento ao tráfico de pessoas seja usada no combate à imigração irregular de brasileiros".

Dentre as medidas a serem adotas, a Declaração prevê a formação técnica dos profissionais, campanhas de informação, conhecimento mútuo das legislações, diagnósticos/pesquisas/estudos, troca de informações policiais, proteção às testemunhas do tráfico de pessoas, realização de levantamentos periódicos e, principalmente, identificação e apoio às vítimas do Tráfico, dentre outras medidas.

No documento, o tráfico de pessoas é reconhecido como uma grave violação dos Direitos Humanos e a sua prevenção e repressão exigem, necessariamente, uma abordagem multidisciplinar e medidas de apoio e proteção às vítimas, envolvendo entidades governamentais e da sociedade civil numa estratégia de ação conjunta. ${ }^{33}$

\begin{tabular}{|l|l|}
\hline Pontos Fortes & Pontos Fracos \\
\hline $\begin{array}{l}\text { Realização de um Acordo de cooperação } \\
\text { policial e judicial entre países estratégicos } \\
\text { no combate ao tráfico. }\end{array}$ \\
\hline $\begin{array}{l}\text { Realização de um Seminário para discutir o } \\
\text { tema com profissionais da área, dos dois } \\
\text { países. }\end{array}$ \\
\hline
\end{tabular}

\section{4 - REPRESSÃO}

\section{Polícia Federal}

"Ação efetiva dos órgãos de segurança e Justiça, no sentido de investigar e punir os casos de tráfico, investigando e punindo exemplarmente os casos de conivência e/ou participação de autoridades e membros de elites locais".

\footnotetext{
${ }^{32}$ Declarações de Cascais e de Brasília: vide anexos II e III.

33 Fonte: http://www.smm.org.br/boletins2006/boletim ab ma.htm. "Brasil e Portugal assinam acordo de cooperação para a prevenção e repressão do tráfico de pessoas".
} 
Encarregada de investigar os casos de Tráfico de Pessoas no Brasil, a Polícia Federal conta com uma equipe capacitada para combater crimes contra os direitos humanos, formada por servidores que têm mostrado, cada vez mais, experiência e competência no enfrentamento aos crimes contra os direitos da pessoa humana.

A Divisão de Direitos Humanos - DDH, subordinada à Coordenação Geral de Defesa Institucional - CGDI, está localizada no $6^{\mathrm{a}}$ andar do Edifício Sede do Departamento de Polícia Federal e convive, rotineiramente, com investigações de crimes na internet, trabalho escravo, tráfico de pessoas, entre outros crimes de âmbito nacional e contra a integridade humana.

Apesar de contar com uma Divisão especializada no assunto, somente nos últimos 5 anos a Polícia Federal, de fato, tomou consciência da realidade que se fazia em torno desse crime que tomava proporções assustadoras em todo o mundo. Até então, era um tema pouco discutido e algumas poucas prisões eram realizadas, mas acreditava-se ser algo esporádico, sem muita importância.

Foi com a publicação da PESTRAF, em 2002, que, não só a Polícia Federal, mas toda sociedade civil, meio acadêmico e governo se depararam com o grande mal que crescia a "passos largos". Exemplo disso são os dados comparativos de inquéritos instalados pela Polícia Federal nos últimos 11 anos (de 1997 a 15/05/2007).

$\mathrm{N}^{\circ}$ de Inquéritos Instaurados pela Polícia Federal no período de 1997 a 15/05/2007 34

\begin{tabular}{|l|c|c|c|c|c|c|c|c|c|c|c|c|r|}
\hline & 1997 & 1998 & 1999 & 2000 & 2001 & 2002 & 2003 & 2004 & 2005 & 2006 & 2007 & Total & $\%$ \\
\hline Total & 7 & 11 & 20 & 35 & 48 & 39 & 56 & 72 & 119 & 105 & 27 & 557 & 100 \\
\hline
\end{tabular}

Fonte: DDH da Polícia Federal

Percebe-se que o número de inquéritos instaurados a partir de 2003 é maior que os anos anteriores, o que não nos deixa outra conclusão a não ser a de que a PESTRAF teve um papel importantíssimo no cenário nacional do Tráfico de Pessoas e que o aumento no número de inquéritos não quer dizer que existiu um aumento na incidência do crime, mas sim que as investigações passaram a existir com maior freqüência. Vale lembrar que os dados do ano de 2007 se referem até o mês de maio, o que explica a baixa quantidade de inquéritos instaurados.

\footnotetext{
${ }^{34}$ Tabela completa de inquéritos dos últimos 13 anos: vide anexo IV.
} 
É importante deixar claro que muitos inquéritos são frutos de denúncias das próprias vítimas, ou de parentes e amigos, ou mesmo de desconhecidos que percebem a existência do ato criminoso. Essas denúncias podem ser realizadas por meio do número 100, do Disque Denúncia Nacional de Abuso e Exploração Sexual de Crianças e Adolescentes, ou pelo número 3311-8705/8270, exposto nos cartazes da Campanha Nacional de Combate ao Tráfico de Seres Humanos. Este último número de telefone é da DDH, na Polícia Federal, que recebe, anualmente, várias denúncias, como pode ser percebido no gráfico a seguir:

\section{Número de Denúncias recebidas pela Polícia Federal, de 2004 a 20/05/2007*}

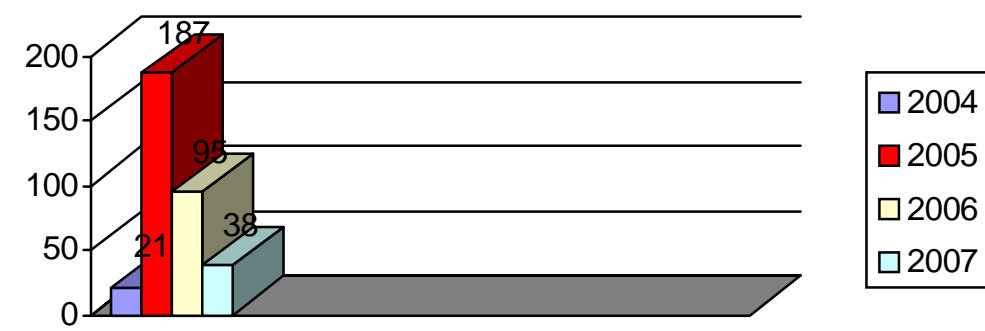

* Fonte: Divisão de Direitos Humanos da Polícia Federal.

Ao fazermos uma comparação entre a tabela de inquéritos instaurados e o gráfico com número de denúncias recebidas na $\mathrm{DDH}$, percebemos que no ano de 2005 a polícia recebeu o maior número de denúncias por telefone, sendo este também o ano com o maior número de inquéritos instaurados. O mesmo acontece com os outros anos. Deduz-se que quanto maior a participação da população, denunciando, maior também será a participação da Polícia investigando. Mais uma vez a informação e a participação da sociedade, mostrando quão importante é a realização de campanhas de conscientização quanto ao tema.

Coincidência ou não, a Campanha Nacional de Combate ao Tráfico de Seres Humanos foi lançada no final do ano de 2004, o que pode ter influenciado para o grande número de ligações no ano seguinte.

Já analisamos as denúncias e os inquéritos, mas o que muita gente não sabe é que muitos inquéritos acabam sendo arquivados por falta de provas ou qualquer outro motivo. Para aqueles, onde o crime é identificado, são montadas Operações Policiais articuladas, se necessário, com outros países que mantêm acordo com o Governo Brasileiro, 
onde as quadrilhas são desbaratinadas, simultaneamente, para impedir "vazamento" de informações.

A seguir, apresentamos quadro quantitativo de Operações Policiais e quantidade de pessoas presas, nos últimos 4 (quatro) anos, pela Polícia Federal. Nos dados anteriores, os números de inquéritos e ligações eram maiores no ano de 2005 , neste caso, as Operações, que ocorrem após a instauração de inquéritos e no final das investigações, aconteceram em maior quantidade no ano seguinte, em 2006, o que deixa a entender que sejam resultado do grande número de denúncias no ano anterior.

Quadro Comparativo das Operações de TSH

\begin{tabular}{|c|c|c|}
\hline Ano & No de Operações $^{\text {No de Pessoas }}$ & \begin{tabular}{c} 
Presas \\
\hline 2004
\end{tabular} \\
\hline 2005 & 2 & 18 \\
\hline 2006 & 4 & 39 \\
\hline $2007^{*}$ & 7 & 65 \\
\hline
\end{tabular}

Fonte: DDH - Departamento de Polícia Federal

* Dados referentes até maio de 2007.

Cooperaram para esse crescente desempenho da Polícia Federal, mas ainda insuficiente, os vários cursos e seminários que seus agentes participaram nos últimos anos no Brasil e no exterior. Os últimos seminários internacionais aconteceram em Buenos Aires, Argentina, no período de 06 a 12/05/2007, onde estiveram presentes 4 (quatro) Delegados de Polícia Federal de três estados brasileiros e em Lima/Peru, no período de 18 a 29/06/2007.

De acordo com Dennis Cali $^{35}$, tramita ainda na Secretaria Nacional de Segurança Pública - SENASP pedido de um curso virtual a ser realizado em todo o território nacional, baseado no Manual - Tráfico de Pessoas para fins à Exploração Sexual, que serviu de base para o primeiro curso virtual do Departamento de Polícia Federal, em 2005.

É sempre importante ressaltar que o Departamento de Polícia Federal pertence ao Ministério da Justiça e que, enquanto instituição do Governo Federal, necessita de apoio por parte deste para o bom êxito nas investigações. Seria injusto citar aqui somente o grande desempenho realizado pela Polícia Federal, principalmente, nos últimos quatro anos, e não fazer referência ao governo que sempre deu liberdade para que a Polícia fizesse o seu trabalho "doa a quem doer" (Lula, 2007).

\footnotetext{
${ }^{35}$ Delegado de Polícia Federal, chefe substituto da Divisão de Direitos Humanos da Polícia Federal.
} 
Seguem algumas das Operações Policiais desencadeadas pela Polícia Federal, referentes ao aliciamento e ao tráfico de Seres Humanos no Brasil, no período de 2005 a 2007.

\section{- Operações Policiais realizadas no período de 2004 a 20/05/2007}

a) Operação Tamar

19/06/2004 - A Polícia Federal deflagrou no dia 19 de junho, em todo país, a Operação "Tamar", que tinha como objetivo reprimir a exploração sexual infantil. A ação é resultado de uma parceria entre a PF e a CPI da Exploração Sexual Infantil, iniciada em 12 de junho de 2003 no Congresso Nacional para investigar denúncias sobre redes de exploração sexual contra crianças e adolescentes existentes no Brasil. A ação da Polícia Federal envolveu mais de 200 policiais federais entre agentes, escrivães e delegados, que foram aos locais indicados pela CPI como pontos onde crianças e adolescentes são explorados sexualmente. A CPI identificou, em mais de seis meses de investigação, quase duas dezenas de locais em capitais e cidades do interior do país onde crianças e adolescentes trabalham como prostitutas e são exploradas por pessoas envolvidas, inclusive com tráfico de armas e seres humanos. Mais de 10 inquéritos abertos, nove pessoas presas em flagrante e mais de 300 casas de entretenimento noturno, entre bares, boates e saunas, vistoriadas pelos agentes da Polícia Federal na Operação Tamar.

Foram realizadas 9 (nove) prisões.

b) Operação Mucuripe

25/10/2004 - A Polícia Federal desarticulou, no dia 25 de outubro, uma quadrilha que movimentava mais de $\mathrm{R} \$ 1$ milhão por mês com o tráfico internacional de mulheres, nas cidades de Fortaleza, Recife e Dortmund, na Alemanha. A operação, batizada de Mucuripe - nome de uma praia do Ceará - , prendeu 11 pessoas que negociavam programas com mulheres brasileiras por meio de um site de uma agência de turismo alemã.

Foram realizadas 11 (onze) prisões.

c) Operação Castelo

03/12/2004 - A Operação Castelo aconteceu dia 3 de dezembro, no estado de Goiás, e visou reprimir o tráfico internacional de seres humanos. Foram presas sete pessoas, a partir de denúncia sobre o embarque de mulheres aliciadas para prostituição na Espanha. Também 
foram cumpridos 16 Mandados de Busca e Apreensão em estabelecimentos comerciais e residências.

Foram realizadas 7 (sete) prisões.

d) Operação Castanhola

14/04/2005 - Com objetivo de desarticular uma quadrilha que atuava no tráfico internacional de mulheres para Espanha e Portugal, a Operação Castanhola foi realizada no dia 14 de abril. Foram 7 pessoas presas na cidade de Anápolis. Também aconteceram ações de repressão na Espanha e Portugal, que resultaram na prisão de 5 pessoas na cidade de Santander (Espanha).

Foram realizadas 12 prisões.

e) Operação Babilônia

05/08/2005 - A Operação Babilônia prendeu, no dia 05 de agosto, no estado de Goiás integrantes de uma quadrilha internacional envolvida com o tráfico de seres humanos. A ação aconteceu simultaneamente na Espanha, com a prisão de uma envolvida. Ao todo foram presas sete pessoas.

Foram realizadas 7 prisões.

f) Operação Êxodo

03/11/2005 - A Polícia Federal desencadeou, no dia 03 de novembro, a operação Êxodo com o objetivo de desmantelar uma quadrilha especializada em tráfico internacional de seres humanos. A quadrilha aliciava brasileiros para entrada ilegal nos Estados Unidos através do México. Estima-se que 120 pessoas eram enviadas, mensalmente, pela quadrilha. Foram presas 6 pessoas e cumpridos 13 mandados de busca e apreensão.

Foram realizadas 6 prisões.

g) Operação Tarantela

21/03/2006 - Desencadeada no dia 21 de março, a Operação Tarantela prendeu integrantes de uma organização criminosa especializada no tráfico internacional de seres humanos com o fim de exploração sexual. Os criminosos atuavam em Goiás, Mato Grosso do Sul, Mato Grosso e Minas Gerais aliciando e remetendo travestis para a Itália.

Foram realizadas 5 prisões. 
h) Operação Tarô

28/03/2006 - A Polícia Federal, em conjunto com a Polícia Judiciária Suíça, deflagrou no dia 28 de março, a Operação Tarô para desarticular uma organização criminosa internacional que praticava o tráfico de mulheres para fins de exploração sexual. As investigações, que iniciaram em 2005, descobriram que o grupo era liderado por um suíço, que por intermédio de aliciadores, recrutava mulheres brasileiras em Belo Horizonte e Região Metropolitana, enviando-as para prostituição em Zurique, Suíça.

Foram realizadas 12 prisões.

i) Operação Lusa

18/06/2006 - A Polícia Federal deflagrou, no dia 18 de junho, a Operação Lusa para desarticular uma quadrilha envolvida com o tráfico de mulheres para fins de exploração sexual. Foram presas duas pessoas, sendo uma estrangeira e um motorista de táxi, que intermediavam a ida de mulheres para a Europa com fins de prostituição. A Polícia também deteve cinco brasileiras que embarcariam com destino à cidade do Porto (Portugal), que foram liberadas depois de prestarem esclarecimentos.

Foram realizadas 2 prisões.

j) Operação Mediador III

03/08/2006 - Policiais Federais da Superintendência Regional da PF no Espírito Santo prenderam nesta quinta-feira, 03, no Aeroporto de Vitória (ES) e no município de Serra (ES), uma quadrilha que traficava pessoas para a Europa. A operação chamada de "Mediador III" teve início às 10:00 horas, ocasião em que os federais prenderam em flagrante no Aeroporto de Vitória três homens quando tentavam embarcar uma jovem para o exterior. Em seguida, os policiais, cumprindo Mandado de Prisão Preventiva, expedido pela Justiça Federal, prenderam outros integrantes da quadrilha no bairro Cidade Continental, no município de Serra, região metropolitana da Grande Vitória (ES).

Foram realizadas 2 prisões.

I) Operação Castela e Madri

06/09/2006 - A Superintendência Regional da Polícia Federal em Goiás desencadeou, no dia 6 de setembro, as operações Castela e Madri. As ações tiveram como objetivo prender 
integrantes de quadrilhas especializadas em tráfico de mulheres para fins de exploração sexual. Além de Goiás, as operações aconteceram simultaneamente na Espanha.

m) Operação Caraxué

18/10/2006 - Na manhã do dia 18 de outubro, a Polícia Federal deflagrou a Operação Caraxué com o objetivo de identificar e prender uma quadrilha especializada no aliciamento de pessoas para o exercício da prostituição na Europa.

Foram realizadas 10 prisões

n) Operação Afrodite

14/12/2006 - A Polícia Federal prendeu, no dia 14 de dezembro, durante a operação Afrodite, oito pessoas envolvidas com um esquema de aliciamento e tráfico de seres humanos. Sete pessoas foram presas com autorização da $7^{\text {a }}$ Vara Federal de São Paulo. A oitava prisão foi feita em flagrante, contra o marido de uma das presas, que portava entre seus documentos o cartão bancário da conta que recebia os depósitos, frutos das ações delituosas.

Foram realizadas 8 prisões.

o) Operação Afrodite II

24/12/2006 - A Polícia Federal em São Paulo, por meio da Delegacia de Defesa Institucional, deflagrou, na manhã do dia 24 de dezembro, a Operação Afrodite II no combate ao tráfico nacional e internacional de mulheres. Em continuidade às investigações que desencadearam a Operação Afrodite, Agentes da Polícia Federal, em São Paulo, cumpriram mandados de prisão, expedidos pela $8^{a}$ Vara Federal, com o objetivo de prender criminosos que aliciavam mulheres para se prostituírem obtendo vantagem financeira.

Foram realizadas 2 prisões.

p) Operação Sodoma

22/01/2007 - A operação "Sodoma" teve início durante a tarde do dia 22 de janeiro, quando os federais, em cumprimento a Mandado de Prisão Preventiva expedido pela Justiça Federal, prenderam no Aeroporto de Vitória três mulheres integrantes de uma quadrilha que traficava pessoas para a Europa.

Foram realizadas 3 prisões. 


\begin{tabular}{|l|l|}
\hline Pontos Fortes & Pontos Fracos \\
\hline $\begin{array}{l}\text { Aumento no número de Operações realiza- } \\
\text { das. }\end{array}$ & $\begin{array}{l}\text { O número de profissionais policiais e de } \\
\text { apoio ainda não é o suficiente. }\end{array}$ \\
\hline $\begin{array}{l}\text { Maior investimento em capacitação de pes- } \\
\text { soal. }\end{array}$ & \\
\hline Apoio governamental. & \\
\hline
\end{tabular}

\section{Polícia Rodoviária Federal}

"Ação efetiva dos órgãos de segurança e Justiça, no sentido de investigar e punir os casos de tráfico, investigando e punindo exemplarmente os casos de conivência e/ou participação de autoridades e membros de elites locais".

Recomendação da PESTRAF, 2002.

De acordo com a PESTRAF, em 2002, existiam no Brasil 241 rotas de tráfico de pessoas. Dessas, 110 corresponderiam a rotas interestaduais e intermunicipais, "demonstrando que, em números absolutos, o tráfico interno é quase tão expressivo quanto o internacional". ${ }^{36}$

"A análise do conjunto das rotas revela que, na maioria das vezes, elas saem do interior dos Estados (cidades de pequeno, médio ou grande porte) em direção aos grandes centros urbanos ou para as regiões de fronteira internacional".(PESTRAF, 2002)

Ainda de acordo com a PESTRAF, "(...) a distribuição dos tipos de transporte terrestres apresenta um certo equilíbrio, com táxis e caminhões figurando como os veículos preferidos, seguindo por automóveis e por ônibus. Isso significa que todas estas rotas são construídas a partir de rodovias federais que se comunicam com diferentes Estados".

Depois de verificados esses estudos, nota-se a importância de se investir e acreditar na Polícia Rodoviária Federal, dada sua importância no combate e repressão ao tráfico de pessoas, principalmente de crianças e adolescentes.

De acordo com o órgão, existem pelo menos 1.918 pontos vulneráveis à exploração sexual de crianças e adolescentes nos 60 mil quilômetros de estradas federais. Em 2005, foram registrados 855, e até o final de 2006 eram 1.222. De acordo com a Polícia Rodoviária, isso não significou um aumento nos casos, mas sim um maior poder de identificação por parte do órgão.

\footnotetext{
${ }^{36}$ PESTRAF, 2002.
} 
A PRF destaca que os principais pontos de prostituição infantil nas estradas estão nos postos de combustíveis, nos bares, nos restaurantes e nas casas de prostituição às margens das rodovias.

De acordo com o Deputado Luiz Couto ${ }^{37}$ existem atualmente 290 pontos onde a exploração sexual é praticada no estado de Minas Gerais, quando no ano anterior o registro era de 190 pontos. "Nós temos que responsabilizar todos aqueles que não tomam atitudes para erradicar a exploração infantil".

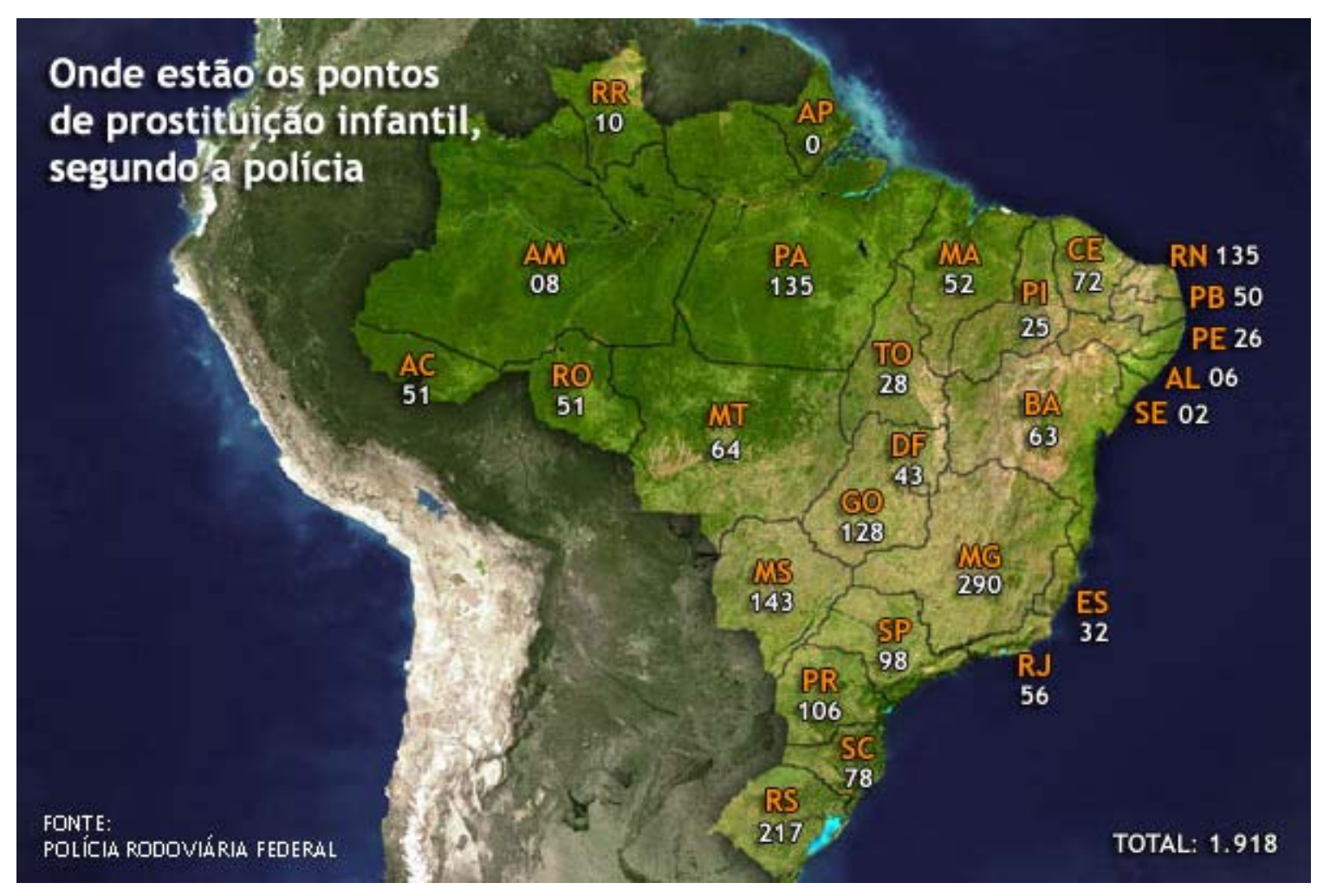

Só em 2006, a PRF encaminhou aos Conselhos Tutelares 127 crianças em situação de exploração sexual nas estradas do país. No ano de 2007, até o mês de maio, esse número já era de 65, o que corresponde à metade do ano anterior.

Vale a pena capacitar e conscientizar esses profissionais tão importantes no combate ao tráfico de pessoas, mostrando-nos que essa é uma luta difícil, mas possível de ser vencida, desde que exista vontade, dedicação, estratégia e investimento.

\footnotetext{
${ }^{37}$ Presidente da Comissão de Direitos Humanos da Câmara dos Deputados.
} 


\begin{tabular}{|l|l|}
\hline Pontos Fortes & Pontos Fracos \\
\hline Aumento no número de apreensões. & $\begin{array}{l}\text { O número de profissionais ainda não é o } \\
\text { suficiente. }\end{array}$ \\
\cline { 1 - 1 } Maior investimento na área. & \\
\cline { 1 - 2 } Apoio governamental no combate ao crime. & \\
\hline
\end{tabular}

\section{5 - PREVENÇÃO}

\section{Disque Denúncia Nacional de Abuso e Exploração Sexual de Crianças e Adolescentes} "Programas que incentivem a denúncia e garantam a segurança e a reinserção social das vítimas".

Recomendação da PESTRAF, 2002.

O Disque Denúncia Nacional de Abuso e Exploração Sexual de Crianças e Adolescentes tem como objetivo receber denúncias de abuso e/ou exploração sexual contra crianças e adolescentes em todo o território nacional. O Serviço funcionava através do número 0800990500 e foi extinto no final do ano de 2002.

Foram alguns meses de reivindicação por parte da Sociedade Civil que fizeram com que o Disque Denúncia voltasse a funcionar em 15/05/2003, através da lei $n^{\circ} 10$ 683/03, porém agora com um novo número, o 100, estrategicamente escolhido, haja vista ser de apenas 3 (três) dígitos e de fácil memorização, e com nova gestão e parcerias: saía a ABRAPIA e entrava a Secretaria Especial de Direitos Humanos - SEDH/PR, com financiamento anual da Petrobrás e capacitação e Recursos Humanos do CECRIA ${ }^{38}$.

No anexo do Ministério da Justiça funciona o Serviço de Atendimento de Demandas - SAD, com 8 (oito) pontos de atendimentos, onde os atendentes são contratados pelo CECRIA como prestadores de serviço. O Serviço funciona gratuitamente todos os dias da semana, inclusive finais de semana e feriados, das $8 \mathrm{~h}$ às $22 \mathrm{~h}$.

Ao discar para o número 100, o denunciante tem a oportunidade de escolher entre consultar o telefone do Conselho Tutelar de sua cidade ou falar com um atendente para fazer sua denúncia. Escolhendo a $2^{\mathrm{a}}$ opção o denunciante deve responder a perguntas que servirão para preencher um formulário com os dados da vítima, do abusador e, se concordar, com seus dados pessoais. Efetuando o atendimento, o denunciante recebe um

\footnotetext{
${ }^{38}$ Centro de Referência, Estudos e Ações sobre Crianças e Adolescentes. Organização não-governamental voltada para a área de exploração sexual de crianças e adolescentes.
} 
número de protocolo que o permitirá, após 15 dias, ligar e acompanhar o destino de sua denúncia. Passado esse período e ciente do destino dado à denúncia, o Disque Denúncia já não se responsabiliza em informar o trâmite completo do processo, uma vez que não existe um retorno certo dos órgãos acionados.

As denúncias recebidas têm o prazo máximo de 24 horas para serem encaminhadas aos devidos órgãos responsáveis. São eles: Ministério Público Federal ou Estadual, Conselhos Tutelares, Delegacias Especializadas, Polícias Civil, Militar, Rodoviária ou Federal e a REDESAP ${ }^{39}$, com exceção das consideradas urgentes ${ }^{40}$, as quais são repassadas imediatamente a esses órgãos, pela gravidade e peculiaridade do caso, como por exemplo, o abuso ou exploração de crianças menores de 3 anos de idade, tráfico de pessoas ou mesmo crianças encontradas suspeitas de serem vítimas de desaparecimento.

Apesar de sua nomenclatura, o Serviço não se restringe ao atendimento apenas de denúncias referentes ao abuso e/ou exploração sexual de crianças e adolescentes, mas também de Tráfico de Pessoas, independentemente de sua idade, e do paradeiro de crianças tidas como desaparecidas. Vale lembrar que a grande maioria das denúncias recebida é de negligência dos pais e não necessariamente de abuso e exploração.

As ligações no "Call Center" são constantes e de grande impacto psicológico, o que levou o Serviço a oferecer a seus funcionários atendimento psicológico uma vez por semana, podendo ser $3^{\mathrm{a}}$ ou $5^{\mathrm{a}}$ feira.

A pretensão é que esse serviço de repasse das denúncias recebidas seja feito on-line para todos os estados do país para agilizar o processo. Por enquanto está em fase de teste apenas com os Ministérios Públicos do estado de São Paulo e do Distrito Federal. Isso se deve, de acordo com Marli Baptistella ${ }^{41}$, dentre outros fatores, à falta de articulação em rede com os demais estados da Federação.

Segundo Marli, no ano passado foi realizado um Seminário com representantes de diversas instituições dos vários estados para decidirem sobre uma "porta

\footnotetext{
${ }^{39}$ Rede Nacional de Identificação de Crianças e Adolescentes desaparecidas.

${ }^{40}$ Tráfico e/ou desaparecimento de mulheres e/ou crianças e/ou adolescentes; Nível de agressão física intensa e/ou situação em que a vítima apresente sinais das lesões (presença de hematomas, etc); Crianças até 6 anos; Envolvimento de autoridades e pessoas influentes e outras que pelo exercício do seu poder no local da ocorrência, ou sobre a situação denunciada, possam exercer algum tipo de interferência prejudicando as providências de proteção das vítimas e responsabilização dos agressores; Denúncias de "sites" de pornografia e pedofilia pela internet; Denúncias com alegação de consumo/tráfico de drogas ilícitas e/ou ilícitas por crianças e adolescentes; Tentativa ou ameaça de abuso sexual contra crianças e adolescentes cuja vítima tenha idade até 14 anos; Pessoa com deficiência.

${ }^{41}$ Consultora Técnica do Serviço Disque Denúncia.
} 
de entrada" das denúncias, porém apenas os estados do Mato Grosso do Sul e Ceará responderam ao apelo, o que evidencia uma total falta de compromisso com a causa.

Um dos maiores problemas enfrentados pelo Disque Denúncia hoje é a falta de sensibilidade e respeito por parte de pessoas da própria sociedade, pois, de acordo com a Supervisora do Disque Denúncia, Josemarie Siqueira, cerca de 55\% das ligações são provenientes de trotes ou de pessoas que acreditam estarem ligando para os Serviços de Informações, número 102. Além disso, a Operadora de Telefonia Celular Brasiltelecom é detentora do número ${ }^{*} 100$, que tem como destino a Caixa Postal do cliente. Josemarie explica que muitos desses clientes acabam ligando apenas o número 100, o que contribui para congestionar as linhas do Serviço.

Além desse atendimento, o Disque Denúncia Nacional de Abuso e Exploração Sexual de Crianças e Adolescentes já conta com o Serviço de Escuta Especializada, utilizado para rastrear ligações não identificadas e que oferecem fortes indícios que necessitam ser investigados, como é o caso de crianças que ligam denunciando, mas não sabem informar o endereço que se encontram, ou pedófilos que muitas vezes ligam e relatam suas atitudes criminosas, pelo puro prazer de compartilhar suas ações, ou até mesmo aqueles trotes constantes que, no fundo, atrás das "brincadeiras", têm algo para denunciar, mas não conseguem falar, normalmente, por sentirem medo.

A Supervisora do Serviço, além de sua institucionalização, defende a realização de campanhas coletivas de conscientização, periodicamente, juntamente com outros "Call Center's". Josemarie ressalta que campanhas coletivas contribuem para a diminuição dos trotes ou ligações irresponsáveis.

Apesar de receber um número considerável de ligações com este propósito, o serviço de denúncia de Tráfico de Pessoas tem colaborado muito para o enfrentamento da questão. Segue gráfico estatístico, referente aos tipos de violência nas denúncias categorizadas de 2003 a 20/03/07. 

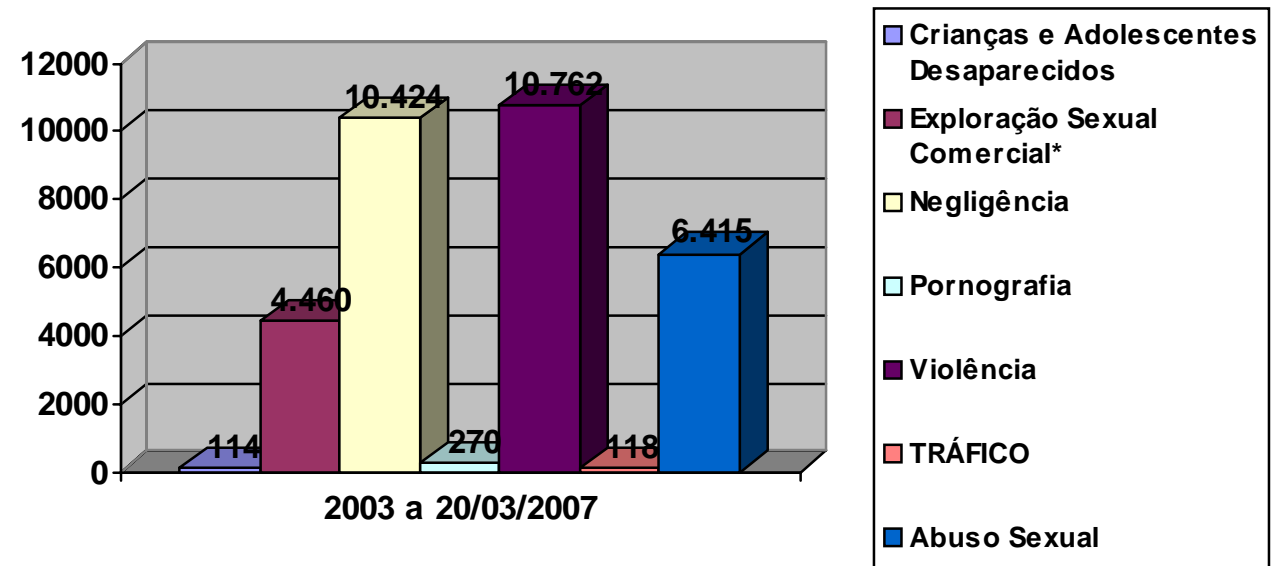

* Atividade Autônoma, Exploração por terceiros, Exploração por terceiros em situação de escravidão; Prostituição e Turismo Sexual.

\begin{tabular}{|l|l|}
\hline Pontos Fortes & Pontos Fracos \\
\hline Existência do Disque - Denúncia & $\begin{array}{l}\text { Não se têm informações de quais denúncias } \\
\text { resultaram em decisões judiciais ou se tiveram } \\
\text { algum seguimento, o que não permite novas } \\
\text { políticas públicas, por não se ter conhecimento } \\
\text { da eficiência do programa. }\end{array}$ \\
\hline $\begin{array}{l}\text { Troca do número por um de apenas } 3 \\
\text { dígitos, o que facilita o acesso. }\end{array}$ & $\begin{array}{l}\text { Não é institucionalizado. Ainda não se encontra } \\
\text { dentro da estrutura do Governo. }\end{array}$ \\
\hline $\begin{array}{l}\text { Divulgação do Programa em emissora e e } \\
\text { Programa de canal aberto - Siga Bem } \\
\text { Caminhoneiro/SBT. }\end{array}$ & $\begin{array}{l}\text { Orepasse on-line das informações Urgentes se } \\
\text { restringe, por enquanto, apenas aos estados de } \\
\text { SP e DF. }\end{array}$ \\
\hline Abrangência Nacional e Gratuito. & $\begin{array}{l}\text { 55\% das ligações são provenientes de trotes ou } \\
\text { enganos. }\end{array}$ \\
\hline $\begin{array}{l}\text { Tempo máximo de 24 h para repasse } \\
\text { das denúncias e repasse imediato para } \\
\text { as consideradas UGENTES. }\end{array}$ & $\begin{array}{l}\text { Pouca divulgação pelas mídias de massa. } \\
\text { A Supervisora sugere Divulgação em massa com } \\
\text { os demais "Call Center's" periodicamente (essa } \\
\text { divulgação coletiva dificultaria a realização de } \\
\text { trotes). }\end{array}$ \\
\hline $\begin{array}{l}\text { Funciona todos os dias, inclusive } \\
\text { feriados, das 8h às 22h. }\end{array}$ & $\begin{array}{l}\text { Apenas depois de 15 dias o denunciante tem } \\
\text { notícias quanto ao destino da denúncia. }\end{array}$ \\
\hline $\begin{array}{l}\text { Também recebe notícias de crianças } \\
\text { desaparecidas e de vítimas (qualquer } \\
\text { idade) do Tráfico de pessoas. }\end{array}$ & $\begin{array}{l}\text { Mesmo número utilizado pela caixa postal da } \\
\text { Brasiltelecom, ocasionando muitas ligações por } \\
\text { engano. }\end{array}$ \\
\hline $\begin{array}{l}\text { Emissão de um número de protocolo } \\
\text { para acompanhar o processo. }\end{array}$ & $\begin{array}{l}\text { Falta de colaboração dos órgãos que fazem } \\
\text { parte da Rede. "Apenas CE e MS responderam } \\
\text { ao apelo de indicar uma "porta de entrada" para } \\
\text { as denúncias". }\end{array}$ \\
\hline
\end{tabular}


Repasse on-line das informações diretamente aos devidos pontos de encaminhamento da denúncia (PF, MP, CREAS, DP...). Os recursos financeiros repassados são aconteceu o abuso. suficientes para o total funcionamento do programa.
Os atendentes do Serviço não conseguem dar informações quanto ao andamento do processo depois de repassado para o órgão responsável do respectivo Estado da Federação onde

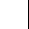

\section{Campanha Nacional de Combate ao Tráfico de Seres Humanos}

"Elaboração e publicação de materiais de informações e de formação. Divulgação em massa (através de cartilhas, folder's e outros) nas escolas, nas boates, nas praias, nas agências de modelos e demais locais onde se encontram vítimas preferenciais, de informações sobre as formas de aliciamento para o tráfico de mulheres, crianças e adolescentes".

Recomendação da PESTRAF, 2002.

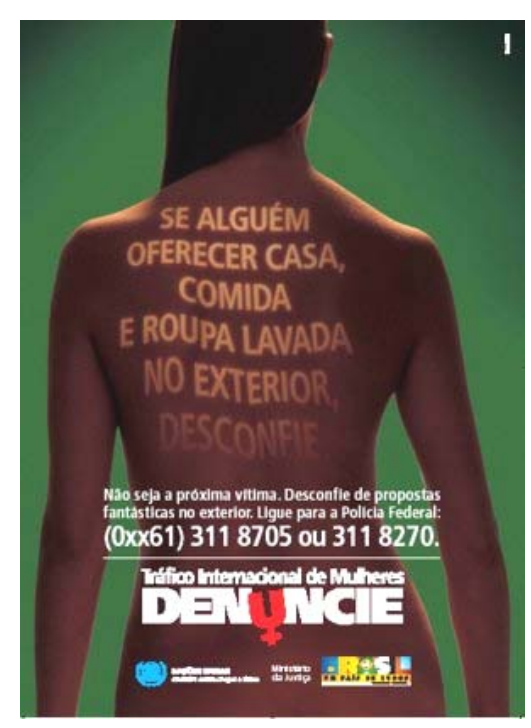

Após a publicação da PESTRAF, em 2002, a realidade do Tráfico começou a se tornar mais evidente, o que mobilizou a sociedade civil e o Governo para a causa. Dia 06 de outubro de 2004, o Ministério da Justiça, juntamente com o UNODC, lançaram, em Goiânia/GO, a Campanha Nacional de Combate ao Tráfico de Seres Humanos, que se tornaria uma grande arma de combate e conscientização. A escolha da cidade foi estratégica, devido o estado de Goiás ser considerado um verdadeiro "celeiro" de novas vítimas do crime.

A Campanha é voltada para as vítimas em potencial e seus familiares, e tem como objetivo "conscientizar a população sobre o problema do tráfico de Pessoas, prevenir esse tipo de crime e facilitar a ação da Polícia Federal no enfrentamento das redes criminosas".42 Entraram como parceiros a Infraero, o Programa Nacional de DST/Aids do Ministério da Saúde, a Secretaria de Comunicação da Presidência da República e a Polícia Federal.

\footnotetext{
${ }^{42}$ UNODC e Brasil lançam campanha contra Tráfico Internacional Seres Humanos. Site: www.unodc.org.br.
} 
Para Reiner Pugs ${ }^{43}$, além da conscientização, é necessário que as pessoas se previnam: "E preciso alertar as pessoas para a existência do crime, alertar que é difícil que exista aquele sonho milagroso da Cinderela, alertar as populações dos perigos e para que elas possam procurar as autoridades dos países para onde estão indo. É preciso tentar mais informações do tipo: quem está convidando e porque está convidando, além de quais os locais que podem me receber se tiver algum problema, endereço de consulado, polícia".

$\mathrm{Na}$ ocasião, o então Ministro da Justiça, Márcio Thomaz Bastos, demonstrou uma total adesão ao enfrentamento do crime e, de acordo com o Ministro, essa também é uma posição do Governo Lula: "É um crime que tem que ser tratado de forma diferenciada, porque é sutil e, muitas vezes, disfarçado por outras práticas legais". O Ministro ainda ressalta que este, diferentemente de muitos outros, necessita de um trabalho diferenciado e em conjunto com outros setores: "Para combatê-lo é preciso trabalhar com sofisticação e em rede".

De acordo com o Ministério da Justiça, o fato de tantas autoridades do poder público estarem presentes na cerimônia fez com que a repercussão na imprensa escrita e principais telejornais ultrapassem as expectativas.

A Campanha consiste na distribuição de filipetas informativas nos novos passaportes emitidos pela Polícia Federal das cidades de São Paulo, Rio de Janeiro, Goiás, Ceará e Distrito Federal para as mulheres entre 18 e 45 anos. Cartazes são expostos na Polícia Federal e locais de emissão de passaportes, e nas áreas de embarque dos aeroportos internacionais de São Paulo e Rio de Janeiro. Alguns spot's serão transmitidos em cidades identificadas como de origem das vítimas.

Além desses materiais também será distribuído um porta-camisinha, porém, voltada exclusivamente para os profissionais do sexo. De acordo com o Delegado de Polícia Federal Dennis Cali ${ }^{44}$, uma grande parte das vítimas já trabalha como profissionais do sexo, ou teve algum envolvimento com redes de prostituição.

Além do preservativo, doado pelo Programa Nacional de DST/Aids, o portacamisinhas traz dicas sobre como evitar o aliciamento pelas redes de TSH

Os cartazes impressos transmitem forte comoção ao retratarem uma mulher nua, suposta vítima do tráfico, de costas com um dos dizeres: "Primeiro eles tiram o passaporte, depois a liberdade" ou "Se alguém oferecer casa, comida e roupa lavada no exterior, desconfie". Após a mensagem, segue: "Não seja a próxima vítima. Desconfie de

\footnotetext{
${ }^{43}$ Coordenador do programa de Prevenção ao Crime e Redução da Oferta de Drogas.

${ }^{44}$ Delegado da Divisão de Direitos Humanos do Departamento de Polícia Federal.
} 
propostas fantásticas no exterior. Ligue para a Polícia Federal". O número da Divisão de Direitos Humanos do Departamento de Polícia Federal ${ }^{45}$ segue à mensagem.

A campanha obteve tanto êxito, que muitas embaixadas em Brasília, por iniciativa própria, divulgaram as mesmas peças. Além das embaixadas, encontrou adeptos até mesmo em Cabo Verde e Portugal.

Uma campanha de alcance nacional pode ser considerada uma grande conquista para a questão do tráfico de pessoas. O acesso à informação está cada vez mais fácil, seja através de cartazes, de filipetas, ou até mesmo por telenovelas, como foi o caso da personagem Suzi ${ }^{46}$ da novela Belíssima, quase vítima de uma rede de aliciadores que mantinha uma falsa Agência de Modelos. A personagem foi resgatada antes do embarque, graças a uma denúncia à Polícia.

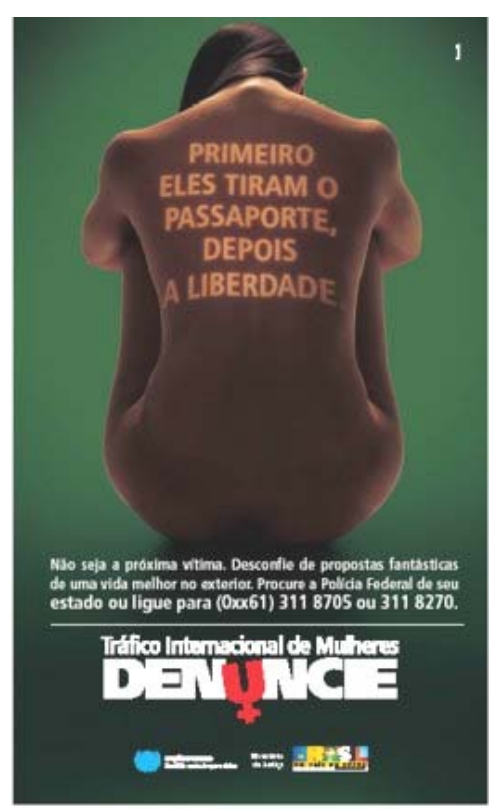

Foi graças a campanhas como essa que hoje o tema é discutido em seminários de Direitos Humanos e programas de televisão, tornando-se possível que não só técnicos e pesquisadores da área conheçam o assunto, mas antes de tudo, as possíveis vítimas possam se informar, se resguardarem e se preservarem. E para que isso aconteça, nada melhor do que a divulgação em massa para a população.

\begin{tabular}{|l|l|}
\hline Pontos Fortes & Ponto Fraco \\
\hline $\begin{array}{l}\text { A existência de uma campanha tão bem } \\
\text { articulada }\end{array}$ & $\begin{array}{l}\text { Não se fala em divulgação nas rodoviárias } \\
\text { interestaduais e fronteiras com países } \\
\text { vizinhos, apenas em aeroportos e em locais } \\
\text { de emissão de passaportes. }\end{array}$ \\
\cline { 1 - 2 } $\begin{array}{l}\text { Fpoio de órgãos estratégicos: Polícia } \\
\text { Federal, Infraero, Ministério da Saúde... }\end{array}$ & \\
\hline $\begin{array}{l}\text { Mensagens de Fácil entendimento pela } \\
\text { Maior divulgação em cidades } \\
\text { diagnosticadas como sendo de origem das } \\
\text { vítimas }\end{array}$ & \\
\hline
\end{tabular}

\footnotetext{
${ }^{45}$ O número do telefone é (0xx61) 3118705 ou 3118270.

${ }^{46}$ Interpretada pela atriz Juliana Kametani.
} 


\section{Considerações Finais}

No decorrer desses últimos 5 (cinco) anos, o tráfico de pessoas ficou em evidência nas pautas de discussão das autoridades governamentais brasileiras. Foram realizadas campanhas, cursos, pesquisas, serviços, investigações e, inclusive, um Plano Nacional está sendo formulado com a finalidade de enfrentar esta questão do Tráfico de Pessoas. As investigações policiais aumentaram consideravelmente em relação aos anos anteriores e a sociedade já está mais familiarizada com o tema. Até mesmo o Código Penal foi alterado para que se adequasse à realidade brasileira.

A atuação do Estado aumentou, porém os índices de incidência do crime também cresceram. Diante dessa afirmação, concluímos que o Estado agiu, mas não o suficiente para enfrentar de "igual para igual" a ação dos aliciadores desse tipo de tráfico.

Apesar das várias medidas adotadas, os índices de incidência do crime continuam crescendo.

Das dezenas de recomendações contidas na PESTRAF, apenas 10 recomendações se fizeram presentes neste estudo, uma vez que as ações estudadas foram apenas aquelas consideradas de maior repercussão no período de 2002 a 2007. Sendo assim, quando avaliadas a postura do Estado, faz-se importante levar esse dado em consideração.

Quando avaliados os pontos considerados fracos, no decorrer do estudo, é possível verificar quão frágeis ainda são as "armas" do governo no enfrentamento ao crime: os dados das pesquisas não são confiáveis, devido à falta de "cuidado" por parte dos pesquisadores, assim como à baixa adesão dos entrevistados, além da incerteza da veracidade das declarações colhidas. Esses estudos ainda não conseguiram responder positivamente à recomendação da PESTRAF, quando propõe a "realização de estudos e de diagnósticos, considerando as múltiplas dimensões do fenômeno (política, social, econômica, jurídica e sociocultural), ampliando a compreensão sobre a violência e privilegiando os recortes de classe, gênero, etnia e idade)".

Outro aspecto que merece ser citado é a impunidade dos infratores nos casos da CPMI e das investigações policiais. Apesar das Polícias Federal e Rodoviária Federal estarem cada vez mais atuantes na repressão e combate ao tráfico e exploração sexual, a quantidade de profissionais ainda é insuficiente e o número de prisões ainda são insignificantes, comparadas à quantidade de inquéritos e indiciados, o que desqualifica as recomendações da PESTRAF para que sejam realizadas "investigação detalhada de crimes 
relacionados ao tráfico..." e que uma "ação efetiva dos órgãos de segurança e da justiça, no sentido de investigar e punir os casos de tráfico, investigando e punindo exemplarmente os casos de conivência e/ou participação de autoridades e membros das elites locais".

O argumento de que a legislação não criminaliza o tráfico de pessoas, em todas as suas complexidades, já não se aplica. O artigo 231 do Código Penal, em resposta à recomendação de "reforçar, no plano jurídico, os referenciais de combate ao tráfico, tais como o Código Penal Brasileiro...", foi modificado e o tráfico de pessoas já está previsto na legislação brasileira, porém ainda podem ser consideradas raras as prisões dos envolvidos nesse tipo de crime.

A Campanha Nacional de Combate ao Tráfico de Seres Humanos, apesar de considerada importante arma contra o crime, se mostrou falha ao ter sua divulgação restrita às rotas aéreas, quando o número de rotas interestaduais e intermunicipais, por vias terrestres, está quase equiparado às rotas internacionais.

Sob a recomendação de estabelecer acordos diplomáticos internacionais, através de protocolos de intenções entre países envolvidos no cenário do tráfico, o I Seminário LusoBrasileiro sobre Tráfico de Pessoas e Imigração llegal se mostrou ineficiente quando a realidade da discriminação e a incidência do tráfico continua cada vez mais presente entre esses dois países.

O manual Tráfico de Pessoas para fins de Exploração Sexual, desenvolvido pela Polícia Federal e em resposta às recomendações da PESTRAF de "sensibilização, mobilização e capacitação de pessoas..." e "Treinamento dos conselheiros Tutelares e dos profissionais das Delegacias Especializadas...", apesar de se ter mostrado eficiente em seus objetivos, ainda são poucos os cursos direcionados para este fim.

Com vários pontos fracos apontados, o Disque Denúncia Nacional de Abuso e Exploração Sexual de Crianças e Adolescentes ainda não atende as expectativas, tendo em vista as poucas denúncias recebidas desde sua aprovação. A recomendação da PESTRAF para a existência de "Programas que incentivem a denúncia e garantam a segurança e a reinserção social das vítimas" ainda precisa ser concretizado.

Diante dessas ações do Estado no enfrentamento ao tráfico de pessoas para fins de exploração sexual, percebe-se que o Estado não tem atuado como deveria e que o crime continua, cada vez mais presente na realidade brasileira. Suas ações, apesar de existirem, não renderam o necessário a ponto de serem consideradas exituosas. 
A ausência de políticas públicas eficientes, capazes de enfrentar o eminente estado de pobreza que leva essas pessoas a procurarem alternativas à sua condição social não permite que esse quadro se reverta. Mais do que uma polícia bem equipada e capacitada, para que o tráfico de pessoas e outras centenas de crimes existentes no Brasil e no mundo sejam sanados, é preciso uma atuação mais incisiva no combate à pobreza e desigualdade social, com a mesma ênfase da coerção. 


\section{Bibliografia}

ADITAL. Disque Denúncia. Disponível em http//www.adital.com.br/site/noticia.asp?lang=PT\&cod=21518.

BRASIL. Ministério da Justiça. Convenção das Nações Unidas contra o Crime Organizado Transnacional (Convenção de Palermo) e leis nacionais. Brasília. Disponível em http://www.mi.gov.br.

BRASIL. Ministério da Justiça. Departamento de Polícia Federal. Realidade brasileira sobre tráfico de seres humanos, pedofilia, proteção à testemunha e legislação correlata. Brasília, 2005.

BRASIL. Ministério da Justiça. Departamento de Polícia Federa. Tráfico de Seres Humanos será um dos Principais Temas na Assembléia Geral da Interpol. Brasília, Polícia Federal, 2006. Disponível em www.dpf.gov.br/dcs/interpol/not\%edcias/11092006 trafico.htm..

BRASIL. Ministério da Justiça. Política Nacional de Enfrentamento ao Tráfico de Pessoas. Brasília: Ministério da Justiça, 2006.

BRASIL. Ministério da Justiça. Política Nacional de Enfrentamento ao Tráfico de Pessoas. Brasília, 2006.

BRASIL. Ministério da Justiça. Relatório de atividades do Governo Federal, desenvolvidas no Enfrentamento ao Tráfico de Pessoas (2003-2006). In: Cartilha Ministério da Justiça: Política Nacional de Enfrentamento ao Tráfico de Pessoas. Brasília: 2007.

BRASIL. Ministério da Justiça. Secretaria Especial de Direitos Humanos. Dados atualizados do Disque Denúncia Nacional - Maio de 2006. Brasília, 2006.

BRASIL. Ministério da Justiça. Seminário discute Política Nacional de Enfrentamento ao Tráfico de Pessoas. Brasília, Ministério da Justiça, 2006. disponível em http://mj.gov.br/noticias/2006/junho.RLS280606trafico.htm 
BRASIL. Ministério da Justiça. Tráfico de Seres Humanos. Disponível em www.mj.gov.br. Brasília, Ministério da Justiça, 2007.

BRASIL. Secretaria Especial de Direitos Humanos. Presidência da República. Disque Denúncia Nacional de Abuso e Exploração Sexual contra Crianças e Adolescentes - 100. Disponível em: http//www.presidencia.gov.br/estrutura_presidencia]sedh]spdca/exploracao_ sexual.

BRASIL. Secretaria Nacional de Justiça. Ministério da Justiça. Relatório: Indícios de Tráfico de Pessoas no universo de deportadas e não admitidas que regressam ao Brasil via o aeroporto de Guarulhos. Brasília: Secretaria Nacional de Justiça, 2005.

BRASIL. Secretaria Nacional de Justiça. Ministério da Justiça. COLARES, Marcos. Relatório: I Diagnóstico sobre o Tráfico de Seres Humanos São Paulo, Rio de Janeiro, Goiás e Ceará. Brasília: Secretaria Nacional de Justiça, 2004.

BRASIL. Secretaria Nacional de Justiça.Ministério da Justiça. Relatório: O Tráfico de Seres Humanos no Estado do Rio Grande do Sul. Brasília: Secretaria Nacional de Justiça, 2005.

BRASIL/PORTUGAL. Ministério da Justiça/Ministério da Administração Interna de Portugal. Declaração de Brasília. Brasília: 2006.

BRASILEIRAS somam 90 \% das vítimas de tráfico humano. Agência Brasil. Brasília, 2006.

CAMPANHA 16 Dias de Ativismo pelo fim da Violência Contra as Mulheres. Exploração sexual e tráfico de mulheres: um problema mundial. Brasília, 2006.

CASTILHO, Ela Wiecko V. de. Tráfico de Pessoas: da Convenção de Genebra ao Protocolo de Palermo, in: Cartilha Ministério da Justiça: Política Nacional de Enfrentamento ao Tráfico de Pessoas. Brasília: 2007. 
CLIENTES da Prostituição podem vir a ser punidos. Gazeta LUSA.

Disponível em http://rtp.pr/index.php?article=240974\&visual=16

FALEIROS, Vicente de Paula. Redes de Exploração e Abuso Sexual e Redes de Proteção. CECRIA.

FREITAS, Renan Springer de. Bordel Bordéis: Negociando Identidades; Ed. Vozes, Petrópolis 1985.

G1. Hotéis do CE lançam campanha contra prostituição infantil. Disponível em http://g1.globo.com/Noticias/0,,MUI38679-5598,00.html

G1. Polícia Rodoviária localiza 1.918 pontos de prostituição infantil, São Paulo. Disponível em http://g1.globo.com/noticias/0,,MUl38611-5598,00.html

GAATW. Carta Aberta Política e Plano Nacional de Enfrentamento ao Tráfico de Pessoas. Rio de Janeiro, 2006.

GAATW-Aliança Global Contra Tráfico de Mulheres, PEARSON, Elaine. Direitos Humanos e Tráfico de Pessoas: Um Manual. Bangkok, Thailand, 2000.

HAZEU, Marcel. Tráfico de Mulheres, Crianças e Adolescentes para fins de Exploração Sexual na Amazônia.

HAZEU, Marcelo. Políticas Públicas de Enfrentamento ao Tráfico de Pessoas: a quem interessa enfrentar o tráfico de pessoas?, Sodireitos/Jepiara-Belém (PA), CHAME/Salvador (BA), Consórcio Projeto Trama/Rio de Janeiro (RJ). In: Cartilha Ministério da Justiça: Política Nacional de Enfrentamento ao Tráfico de Pessoas. Brasília: 2007.

IBISS-CO. Projeto Direito de Ir e Vir. Tráfico de Seres Humanos: Responsabilizar é Possível. Campo Grande, 2004. 
IMIGRANTES. Tráfico de Seres Humanos. Como no passado O trabalho escravo e as redes de prostituição constituem neste momento, um dos negócios mais lucrativos em todo o mundo. Disponível em http://imigrantes.no.sapo.pt/page3.html

KEMPADOO, Kamala. Mudando o debate sobre o tráfico de mulheres. 2005.

LEAL, Maria Lúcia P. Globalização e Exploração Sexual Comercial de Crianças e Adolescentes. Rio de Janeiro: Save the Children, 2003.

LEAL, Maria Lúcia P; LEAL, Maria de Fátima P; Tráfico de Mulheres, Crianças e Adolescentes para fins de exploração sexual comercial: Um fenômeno transnacional.

LEAL, Maria Lúcia; LEAL, Maria de Fátima. Enfrentamento do Tráfico de Pessoas: um questão possível? in: Cartilha Ministério da Justiça: Política Nacional de Enfrentamento ao Tráfico de Pessoas. Brasília: 2007.

LIMA, Paulo. Contra o tráfico de pessoas. Disponível em www.adital.org.br. Fortaleza, 2006.

LIMA, Renato Sérgio de. O Decreto n 5.948/2006 e o ciclo das políticas públicas de justiça e segurança. Cartilha Ministério da Justiça: Política Nacional de Enfrentamento ao Tráfico de Pessoas. Brasília: 2007.

MARCÃO, Renato. Lei 11.106/2005: Novas modificações ao Código Penal brasileiro. (III) Do lenocínio e do tráfico de pessoas: Art. 227 (Mediação para servir a lascívia de outrem); Art. 231 (Tráfico Internacional de Pessoas): Art. 231-A (Tráfico Interno de pessoas). Disponível em http://www.mundojuridico.adv.br/sis artigos.asp?codigo=148

MARTINEZ, Fabrina. Thaís de que deficiência na legislação dificultam combate ao abuso e exploração sexual. Disponível em http://www.caminhos.uf.ms.br. 07/04/2004.

NIDECKER, Fernanda. Planalto Central na Rota do Tráfico. Jornal do Brasil. 2004. disponível em 
http://www.mre.gov.br/portugueses/noticiario/nacional/selecao_detalhe.asp?ID_RESENHAD AIMPRENSA NACIONAL

O Trabalho da CPMI da exploração sexual: Balanço final. Disponível em http://www.senado.gov.br/web/senador/patriciasaboyagomes/ca/cpmi/oquee.htm

OLIVEIRA, Pedro Américo Furtado de; FARIA, Thaís Dumêt. Do Tráfico para o trabalho forjado à caminhada para o trabalho decente. In: Cartilha Ministério da Justiça: Política Nacional de Enfrentamento ao Tráfico de Pessoas. Brasília: 2007

PAIVA, Leila. Uma reflexão sobre o Programa de Assistência a Crianças e Adolescentes Vítimas de Tráfico para fins Sexuais. Cartilha Ministério da Justiça: Política Nacional de Enfrentamento ao Tráfico de Pessoas. Brasília: 2007.

PEREIRA, Armando. Prostituição, uma visão global. Ed. Pallas S.A., 1976.

PESTRAF. Pesquisa de Tráfico sobre Mulheres, Crianças e Adolescentes para fins de Exploração Sexual Comercial. Brasília: CECRIA, 2002.

PORTUGAL e Brasil adotam estratégias para combater tráfico de seres humanos. Disponível em http://www.embaixadadeportugal.org.br/destaques/detalhe.php?cod noticias $=165$

PORTUGAL e Brasil debatem tráfico de pessoas e imigração ilegal. Disponível em http://diplomaciaenegocios.com.br/ntc.asp?cod=1132.

PORTUGAL. Governo da República Portuguesa. Declaração adaptada no Seminário Luso Brasileiro sobre Tráfico de Pessoas e Imigração llegal. Disponível em www.portugal.gov.bt.

PUNGS, Reiner. Esforços brasileiros no combate ao tráfico de seres humanos/ discurso de abertura do I Seminário Nacional sobre Tráfico de Seres Humanos. 19/05/2005. Disponível em http://www.unodc.org/brazil/pt/articles speechs thb.html. 
ROSÁRIO, Maria do. Relatório da CPMI da Exploração Sexual de Crianças e Adolescentes, síntese. Câmara dos Deputados. Brasília: 2005.

SALES, Lilia Maia de Morais; ALENCAR, Emanuela Cardoso Onofre de; RABELO, Cilana de Morais Soares; COSTA, Andreia da Silva. A Questão do Consentimento da Vítima de Tráfico de Seres Humanos.

SIMÕES, Daniela Martins. Metodologia Científica. Disponível em http://www.fag.edu.br/estagiosadm/documentos/apostilametodologiacientifica.doc. Acesso em 20/06/07.

SMM. Combate à Exploração Sexual Comercial. Deputado: MG tem mais pontos de exploração sexual em rodovias. Diário do Grande ABC. Disponível em http://webmail.dpf.gov.br/src/read body.php?malbox=INBOX\&passed id=1224\&

SPRANDEL, Márcia Anita. Tráfico de Seres Humanos: novas categorias, velhos problemas. SUCUPIRA, Fernanda. Impunidade é um dos grandes vilões no enfrentamento à violência $\begin{array}{llll}\text { sexual. } & \text { Carta } & \text { Maior. } & \text { Disponível }\end{array}$ http://www.girassolidario.org.br/?can cod=9\&con cod=1582

SUÉCIA, S. M. Rainha Silvia da. Tráfico de Crianças. In: Situação Mundial da Infância 2005 (Capítulo 5 -Destaque 1). Disponível em http://www.unicef.org/brazil/sowc05/cap5dest1.htm.

TRÁFICO de mulheres aumenta em MS. Correio do Interior. Disponível em http://www.correiodointerior.com.br/paginas/ler.php?id=24183

Tráfico de Mulheres, A miséria por trás da fantasia: da pobreza à escravatura sexual, uma estratégia Européia Global. Disponível em http://ec.europa.eu/justice home/news/8mars pt.htm.

TRÁFICO DE PESSOAS PARA FINS DE EXPLORAÇÃO SEXUAL. Brasília: OIT, 2005. 
UNODC. UNODC Lança Iniciativa Global para Prevenir e Conter o Tráfico de Seres Humanos. Assessoria de Comunicação. Brasília, 2007.

XAVIER, Clyton Eustáquio. Tráfico de Pessoas. Brasília, Polícia Federal. Divisão de Direitos Humanos, 2007. 


\section{Anexos}

\section{Anexo I}

\section{RECOMENDAÇÕES PARA O ENFRENTAMENTO DO TRÁFICO}

Apresenta-se a seguir, o detalhamento das ações consideradas essenciais para o processo de combate ao tráfico de mulheres, crianças e adolescentes para fins de exploração sexual comercial. Trata-se de um conjunto de propostas que foram surgindo no decorrer da PESTRAF e solidificando-se nos relatórios finais das respectivas regiões.

Não tem a finalidade de esgotar as possibilidades de enfrentamento, permitindo que as instituições envolvidas no processo possam trabalhar melhor suas propostas, adotando, como referência inicial, as contribuições apresentadas a seguir.

\section{Propostas De Enfrentamento}

(a) RECONHECIMENTO E MONITORAMENTO do FEnÔMENO

1. Realização de estudos e de diagnósticos, considerando as múltiplas dimensões do fenômeno (política, social, econômica, jurídica e sociocultural), ampliando a compreensão sobre a violência estrutural e privilegiando os recortes de classe, gênero, etnia e idade;

2. Realização de estudos avaliativos de realidades e indicadores macro-sociais, e de suas relações com o enfrentamento do tráfico;

3. Elaboração e publicação de materiais de informação e de formação. Divulgação em massa (através de cartilhas, folders e outros) nas escolas, nas boates, nas praias, nas agências de modelos e nas demais locais onde encontram-se as vítimas preferenciais, de informações sobre as formas de aliciamento para o tráfico de mulheres, crianças e adolescentes. As vítimas devem ser chamadas a participarem na elaboração destas estratégias.

4. Promover e apoiar debates e ações sobre a responsabilização da mulher traficada, evitando a justificativa da existência do tráfico devido apenas aos atributos naturais da mulher, postura que é discriminatória, revitimizadora, moralista e repressora. O direito de ir e vir, assim como o direito do uso do corpo, devem ser respeitados e garantidos; 
5. Articulação das ONGs nacionais e internacionais que atuam nesse campo, tendo com objetivo a troca de experiências e de informações, bem como a formação de uma agenda de trabalho conjunto, baseada no paradigma dos direitos humanos;

6. Quantificação e qualificação das informações existentes sobre o tráfico, distinguindo-o dos outros tipos de delitos que são notificados;

7. Divulgação e discussão dos resultados da PESTRAF, no CONANDA, no Fórum DCA, nas universidades, nos conselhos de direitos e tutelares, e nos conselhos nacional e estaduais de defesa do direto da mulher;

8. Estruturação de uma dinâmica contínua de monitoramento e de avaliação das ações desenvolvidas.

(b) CONCRETIZAÇÃO DAS AÇÕES

1. Definição da temática do enfrentamento do tráfico como prioridade política das agendas governamentais;

2. Definição de um plano nacional, contendo as principais diretrizes de atuação frente ao fenômeno;

3. Articulação entre os setores do poder público (ONGs) e ONGs, Fóruns, Centros de Defesa e Movimentos Sociais, visando desenvolver ações conjuntas para o enfrentamento do fenômeno;

4. Efetivação de políticas públicas, visando à garantia e à defesa dos direitos das mulheres, crianças e adolescentes em situação de tráfico para fins de exploração sexual;

5. Implementação, em curto prazo, do seguinte conjunto de ações:

- Controle efetivo da entrada e das atividades econômicas de estrangeiros;

- Ação efetiva dos órgãos de segurança e da justiça, no sentido de investigar e punir os casos de tráfico, investigando e punindo exemplarmente os casos de conivência e/ou participação de autoridades e membros de elites locais;

- Preparação do Itamaraty, dos consulados e das embaixadas brasileiras no exterior, no sentido de identificar casos de tráfico e de garantir a proteção e a defesa das mulheres traficadas; 
- Criação de um sistema de informações que permita identificar e controlar as ações das redes de tráfico de seres humanos no Brasil;

- Garantia de rigor na fiscalização da publicidade turística que utiliza apelos eróticos para vender o Brasil como destino turístico;

- Criação de um sistema de qualificação positiva dos estabelecimentos turísticos que não favorecerem o turismo sexual;

- Realização de campanhas públicas que promovam a mudança de cultura e de mentalidade sobre os temas do tráfico de seres humanos para fins de exploração sexual, do turismo sexual, do consumismo, do uso do corpo como alternativa profissional e da desigualdade entre homens e mulheres;

6. Fortalecimento das organizações de mulheres, especialmente as comunitárias, e das iniciativas do movimento de mulheres que permitam a constituição das mulheres enquanto sujeitos individuais e políticos;

7. Integração das políticas públicas municipais de enfrentamento, o que poderia ser feito a partir da elaboração de um plano de ação integrado das secretarias de governo. No entanto, há que se garantir que este plano seja incorporado como política pública de caráter permanente e não como uma política governamental atrelada a determinada gestão política. Pode ser proposta e fiscalizada pelo Conselho de Direitos da Criança e do Adolescente, pelo Conselho Tutelar e pelo Comitê Local de execução do Programa de Combate;

8. Estruturação e reforço, nas instituições que atuam com a problemática, das redes de notificação e de armazenamento de dados;

9. Definição e implementação de um conjunto de ações voltadas para o apoio às vitimas das redes de tráfico;

10.Preparação de bancos de dados, buscando explicitar o fenômeno nos níveis internacional, nacional, regional, estadual e municipal (tratamento global do fenômeno);

11. Cobrar, dos órgãos do sistema jurídico, a priorização e a agilização dos processos. A ineficiência e a morosidade do sistema judiciário nacional afetam, de igual maneira, os sistemas estaduais e locais, sobretudo devido à infinita burocracia que os processos têm 
que enfrentar e à não priorização no julgamento destes crimes, nem quando cometidos contra crianças e adolescentes;

12. Ampliação do entendimento jurídico para o enfrentamento do problema;

13. Aporte de recursos físicos, financeiros e de $\mathrm{RH}$ às instituições de atendimento $\mathrm{a}$ mulheres, crianças e adolescentes;

14. Sensibilização e mobilização da sociedade para a existência e o enfrentamento do fenômeno;

15.Sensibilização, mobilização e capacitação das pessoas que atuam no sistema de atendimento e nos espaços de defesa e de responsabilização;

16. Treinamento dos Conselheiros Tutelares e dos profissionais das Delegacias especializadas, priorizando a visibilidade, o entendimento e o combate ao fenômeno;

17. Articulação das diferentes políticas e programas governamentais existentes, evitando sua fragmentação e fragilização e garantindo o pleno exercício dos direitos do cidadão;

18. Propostas visando à efetiva melhoria das condições de vida de mulheres, crianças e adolescentes em situação de vulnerabilidade social, apoiando as mulheres que correm riscos em países que lhes são estranhos e enfrentando situações quase sempre desconhecidas;

19. Ações contrárias ao tráfico de mulheres, crianças e adolescentes voltadas não só para os países de destino, mas também para os de origem e de trânsito. É necessário que se adote uma postura de repressão em relação aos traficantes, assegurando às vítimas, a proteção de seus direitos humanos;

20.Políticas que apóiem o retorno de mulheres já traficadas, em situação de cárcere privado, exploração sexual, drogadição, alcoolismo, endividamento, e que estejam sem documentos, e sem passagens;

21. Reforçar, no plano jurídico, os referenciais de combate ao tráfico, tais como o Código Penal Brasileiro, a Convenção Contra a Criminalidade Transnacional e o Protocolo Adicional para a Prevenção, Repressão e Punição do Tráfico de Pessoas. O Brasil, ao ratificar uma norma internacional de proteção aos direitos humanos, deveria incorporá-la e aplicá-la, automaticamente; 
22. Ações articuladas para a propositura de política públicas que garantam a devida promoção e proteção às vítimas do tráfico, envolvendo as instâncias do poder público que atuam na repressão e na responsabilização - Polícia, Ministério Público, Defensoria Pública e Magistratura -, as demais organizações governamentais e as organizações não-governamentais;

23. Investigação detalhada de crimes relacionados ao tráfico: desaparecimento; seqüestro; adoção ilegal; prostituição infanto-juvenil; turismo sexual; tráfico de drogas; organizações criminosas; e economias clandestinas;

24. Considerar o dinamismo e a capacidade de reestruturação das redes de tráfico, que se reorganizam rapidamente, de maneira a poder agir livremente, fugindo da interferência do poder público ou da sociedade civil organizada;

25.Programas que incentivem a denúncia e garantam a segurança e a reinserção social das vítimas;

26. Defesa de uma postura mais rígida no cumprimento das leis, reconhecendo a participação de autoridades na exploração sexual de pessoas de todas as idades e de ambos os sexos. Esta participação não pode tornar a solução dos crimes, uma tarefa difícil e tortuosa. Estes indivíduos não podem ser considerados "intocáveis", nem representar perigo a quem se propõe combatê-los;

27. Considerar e enfrentar as diferentes condições que potencializam o desenvolvimento do tráfico nas fronteiras: a duplicidade de moedas circulantes, a base internacional dos investimentos de capital, o intenso fluxo de veículos de transportes sem controle eficaz das aduanas, a circulação da população local entre os países, sem exigências burocráticas e legais, a instabilidade econômica, a existência de um comércio sexual ligado à dinâmica produtiva local, os baixos indicadores de qualidade de vida, renda e empregabilidade, dentre outros;

28. Implementação do Programa Global de Combate ao Tráfico de Seres Humanos Ministério da Justiça - com o objetivo de promover um agir mais intenso e amplo sobre o fenômeno, além de um maior envolvimento dos governos municipais, estaduais e federal, articulados com os Planos de Enfrentamento da Violência Sexual, com o Plano de Segurança e de Direitos Humanos do MJ, com o Programa Sentinela (MPAS/SEAS) e o Programa de DST/AIDS (MS); 
29. Revisão e reformulação do Código Penal Brasileiro, pois, além de tratar o tráfico como situação possível de ser vivenciada somente para as mulheres e em âmbito internacional, não dá conta do tráfico de crianças e adolescentes. Tal revisão mostra-se relevante, também, porque o texto legal supramencionado aborda apenas o tráfico para fins de exploração sexual, recomendando-se a introdução da exploração laboral e do tráfico para o casamento servil;

30. Erradicação do turismo sexual no País, considerando que dentre os indicadores que favorecem a existência do tráfico de pessoas para fins de exploração sexual, esta atividade criminosa ocupa um lugar de destaque;

31.Implantação de Centros de Referência de Atendimento a Mulheres, Crianças e Adolescentes Vítimas de Exploração Sexual, que deverão ter abordagens diferenciadas, de acordo com as especificidades dos casos;

32. Ampliação e fortalecimento do Programa Sentinela, para constituir-se em alternativa eficaz de atendimento às crianças e aos adolescentes. É necessário, também, garantir, via Conselho de Direitos ou de Assistência Social, que o Programa Sentinela seja incorporado como programa permanente e suas metas de atendimento ampliadas;

33. Intervenção das instâncias superiores do sistema de segurança pública nacional, com o auxílio da Divisão de Polícia Criminal Internacional da Polícia Federal (INTERPOL), através de seu Setor de Inteligência, para identificar as redes de tráfico de pessoas, trabalho que deve ser feito por especialistas, devido ao perigo e à necessidade de treinamento especial. No âmbito local, a utilização do expediente das forças tarefa parece ser uma alternativa bastante promissora no sentido de localizar e punir os aliciadores e traficantes;

34.Estabelecimento de acordos diplomáticos internacionais, através de protocolos de intenções, entre os países que foram apontados nas rotas de tráfico, tencionando estabelecer ações conjuntas para combater o tráfico de mulheres, crianças e adolescentes para fins sexuais; 


\section{Anexo II \\ DECLARAÇÃO DE CASCAIS}

O I Seminário Luso Brasileiro sobre Tráfico de Pessoas e Imigração llegal//rregular que teve lugar em Cascais, Portugal, de 22 a 24 de Maio de 2006, reuniu individualidades e peritos na matéria, de ambos os países.

É reconhecido que o tráfico de pessoas se traduz numa grave violação dos direitos humanos e que a sua prevenção e repressão exigem necessariamente uma abordagem multidisciplinar e medidas de apoio e proteção às vítimas, envolvendo entidades governamentais e da sociedade civil, numa estratégia de ação conjunta.

A Declaração de Cascais, resultante da análise da situação atual em ambos os países, efetuada no decurso do Seminário, visa aprofundar os atuais meios de cooperação entre a República Portuguesa e a República Federativa do Brasil, preconizando medidas objetivas concretas ao nível dos mecanismos que previnam e combatam o tráfico de pessoas, bem como das redes criminosas que violam os direitos dos migrantes, as quais constam do Anexo I.

\section{Anexo I}

- Aprofundar a formação técnica dos profissionais na perspectiva de que é necessário uma abordagem mais especializada na identificação e prevenção do tráfico de pessoas e na proteção das vítimas;

- Promover campanhas de informação sobre migração e tráfico de pessoas para sensibilização e esclarecimento da sociedade;

- Aprofundar o conhecimento mútuo da legislação relevante dos dois países e promover estudos comparativos;

- Difundir os instrumentos de cooperação jurídica e judiciária susceptíveis de serem utilizados no combate ao tráfico de pessoas;

- Estimular a elaboração conjunta de diagnósticos (pesquisas/estudos) que traduzam uma visão integrada sobre a temática do tráfico de pessoas para fins de exploração, com a participação da sociedade civil e das Universidades; 
- Realização de campanhas de informação e sensibilização sobre tráfico de pessoas para fins de exploração, visando a promoção de valores culturais, sociais e educativos, no sentido de desencorajar a procura dos serviços de pessoas objecto de exploração;

- Intensificação da cooperação entre os serviços responsáveis pela prevenção do tráfico de pessoas para fins de exploração e apoio às vítimas, por meio da criação e fortalecimento de canais diretos de comunicação;

- Definição de mecanismos conjuntos de sinalização e identificação das vítimas de tráfico de pessoas, com base no princípio da não discriminação;

- Criação de uma rede luso-brasileira de entidades e instituições públicas e privadas que intervenham na prevenção, apoio e repressão do tráfico de pessoas para fins de exploração;

- Cooperação entre autoridades consulares e autoridades competentes do país receptor tendo em vista a proteção da vítima;

- Garantir apoio, nomeadamente psicossocial e jurídico, e proteção à vítima do tráfico de pessoas;

- Assegurar a voluntariedade do retorno, posterior a período de reflexão adequado, e visando a integração na sociedade do país de origem;

- Intensificação dos canais para troca de informação de natureza policial, de modo a que seja partilhada toda a informação relevante, designadamente sobre as melhores práticas de investigação, rotas, modus operandi, redes criminosas de tráfico de pessoas e de imigração ilegal/irregular, bem como sobre a identificação de vítimas para efeito de apoio às mesmas, em ambos os países;

- Salienta-se a importância dos oficiais de ligação, mormente como canal privilegiado de troca de informações;

- Utilização de métodos de análise de informação como forma de prevenção e combate ao Tráfico de Pessoas e às redes criminosas de imigração ilegal/irregular; e,

- Cooperação bilateral na área de proteção de testemunhas de crimes de Tráfico de Pessoas envolvendo Portugal e o Brasil. Para o efeito, realizar-se-ão reuniões entre Autoridades e outros técnicos na área, de ambos os países, com a periodicidade, no mínimo, anual. 


\section{Anexo III}

\section{DECLARAÇÃO DE BRASÍLIA}

A segunda etapa do I Seminário Luso-brasileiro sobre Tráfico de Pessoas e Imigração llegal//rregular realizado em Brasília, Brasil, entre os dias 27 e 29 de novembro de 2006, reuniu individualidades e peritos na matéria de Portugal e do Brasil.

É reconhecido que o tráfico de pessoas se traduz em uma grave violação dos direitos humanos e que sua prevenção e repressão exigem necessariamente uma abordagem multidisciplinar e medidas de apoio e proteção às vítimas, envolvendo entidades governamentais e da sociedade civil, numa estratégia de ação conjunta.

O enfrentamento às redes criminosas responsáveis pelo tráfico (contrabando) de imigrantes também é um assunto urgente que viola a soberania dos Estados e ameaça a segurança dos migrantes e, ao mesmo tempo, possui interface com o tráfico internacional de pessoas.

A Declaração de Brasília, resultante da análise da situação atual em ambos os países, elaborada no decurso das duas etapas do Seminário, visa aprofundar os atuais meios de cooperação entre a República Portuguesa e a República Federativa do Brasil no âmbito dos serviços competentes, preconizando medidas concretas ao nível dos mecanismos que previnam e combatam o tráfico de pessoas, bem como das redes criminosas que violam os direitos dos migrantes, as quais constam do ANEXO I.

Com base nos marcos normativos dos dois países, afirmamos que são princípios norteadores da Declaração de Brasília:

I - respeito à dignidade da pessoa humana;

II - não-discriminação por motivo de gênero, orientação sexual, origem étnica ou social, procedência, nacionalidade, atuação profissional, raça, religião, faixa etária, situação migratória ou outro status;

III - promoção e garantia da cidadania e dos direitos humanos;

IV - respeito a tratados e convenções internacionais de direitos humanos; 
V - universalidade, indivisibilidade e interdependência dos direitos humanos;

VI - transversalidade das dimensões de gênero, orientação sexual, origem étnica ou social, procedência, raça e faixa etária nas políticas públicas.

Brasília, 29 de novembro de 2006

O Diretor-Geral do Serviço de

Estrangeiros e Fronteiras do

Ministério da Administração

Interna de Portugal
Manuel Jarmela Palos

A Secretária Nacional de Justiça do

Ministério da Justiça do Brasil

Claudia Maria de Freitas Chagas

\section{Anexo I}

1. Aprofundar a formação técnica dos profissionais considerados estratégicos no enfrentamento ao tráfico de pessoas, com vista a definir mecanismos conjuntos para promover uma melhor identificação e sinalização das vítimas, com base no princípio da nãodiscriminação;

2. Identificar quais as categorias profissionais que, por sua atuação estratégica, devem receber essa formação técnica específica - segurança, aeroportos, saúde, educação e cultos religiosos, entre outros;

3. Realizar missões de estudos e estágios entre profissionais que lidam com o tema nos dois países;

4. Criar grupos técnicos de trabalho regulares com os seguintes objetivos: a) operacionalizar as ações policiais desencadeadas a partir das declarações de Cascais e de Brasília; $b$ ) identificar as necessidades de formação das entidades de ambos os países no âmbito do enfrentamento ao tráfico de pessoas e elaborar um programa conjunto de aperfeiçoamento, até junho de 2007 ; c) estudar os programas de proteção às testemunhas de crimes de tráfico 
de pessoas existentes, com vistas a torná-los mais humanos e atraentes para as vítimas do tráfico de pessoas.

5. Publicar, até junho de 2007, pelo Ministério da Administração Interna de Portugal e pelo Ministério da Justiça do Brasil, com o apoio do Conselho da Europa, um livro contendo quatro histórias sobre situações típicas de tráfico de pessoas no mundo, cuja distribuição constituirá uma das ações de campanha de esclarecimento sobre o tráfico de pessoas, a ser realizada em data comum, com a participação da sociedade civil.

6. Constituir grupo bilateral de especialistas para efetuar levantamento, até o final de 2007, de todo o acervo legislativo existente em ambos os países com impacto nas matérias de imigração irregular e tráfico de pessoas.

7. Identificar e difundir os instrumentos de cooperação jurídica e policial susceptíveis de serem utilizados no combate ao tráfico de pessoas nos dois países;

8. Realizar, no âmbito dos próximos seminários Luso-brasileiros sobre Tráfico de Pessoas e Imigração Irregular, partir de 2007, oficinas paralelas com a participação de especialistas das seguintes áreas: a) instituições e empresas do trade turístico dos dois países - companhias aéreas, setor hoteleiro, agências de turismo, entre outros, com o objetivo de estudar modelos de cooperação regional e bilateral, desenvolvidas pelo trade turístico, de eficácia comprovada na identificação de possíveis vítima do tráfico de pessoas; $b$ ) serviços de imigração e serviços de proteção e atendimento à vítima, bem como de organizações não governamentais com experiência no tema, com o objetivo de partilhar melhores práticas na identificação da vítima de tráfico de pessoas;

9. As oficinas listadas no item 9 deverão produzir, obrigatoriamente, uma lista alargada de critérios de identificação das vítimas do tráfico que possa ser utilizada em ambos os países.

10. Na perspectiva operacional da identificação das vítimas de tráfico de pessoas, considerase fundamental que seja concretizada, até o final de 2007, a designação de oficial de ligação brasileiro / adido policial em Portugal. 
11. Estimular a procura aos consulados por meio de materiais informativo que ajudem o cidadão a entender as atribuições do consulado. O material deverá ser distribuído não apenas nos consulados brasileiros no exterior, mas também para os brasileiros que deixam o país.

12. Identificar e catalogar os principais integrantes da rede de atendimento e proteção dos dois países, com o objetivo de produzir uma publicação com nomes, endereços, contatos e serviços prestados por cada uma das organizações listadas.

13. Nos casos de recusa de entrada e de deportação, criar uma dinâmica entre os serviços de imigração de Portugal e do Brasil, a partir da experiência piloto do Posto de Acolhimento a Deportados e Não Admitidos do aeroporto internacional de São Paulo, em Guarulhos.

14. Realizar um levantamento periódico sobre os casos atendidos pelo mesmo Posto de Acolhimento, encaminhados pelos serviços portugueses de imigração.

15. Garantir apoio, nomeadamente psicossocial e jurídico, e proteção à vítima do tráfico de pessoas em Portugal e no Brasil e assegurar a voluntariedade do retorno, posterior a período de reflexão.

16. Produzir relatórios anuais, a partir de 2008 , dando conta do apoio psicossocial e jurídico prestado, bem como sobre as medidas protetivas aplicadas às vítimas de tráfico de pessoas em Portugal e no Brasil.

17. Estabelecer métodos operacionais conjuntos de troca e de análise de informação policial, a fim de facilitar o intercâmbio e a cooperação entre os dois países. 


\section{Anexo IV}

Tabela 1 - Tabela de Inquéritos realizados pela Polícia Federal no período de 1995 a $15 / 05 / 2007$

\begin{tabular}{|c|c|c|c|c|c|c|c|c|c|c|c|c|c|c|c|c|}
\hline & 1995 & 1996 & 1997 & \begin{tabular}{l|l}
7 & 1 \\
\end{tabular} & 998 & 1999 & 2000 & 2001 & 2002 & \begin{tabular}{|l|l|}
2003 \\
\end{tabular} & 2004 & 2005 & 2006 & 2007 & 7 Total & $\%$ \\
\hline AC & 0 & 0 & ) & 0 & 0 & 0 & 0 & 2 & & 0 & 0 & 1 & 3 & 1 & 1 & $1,25 \%$ \\
\hline $\mathbf{L}$ & 0 & 0 & 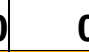 & 0 & 0 & 0 & 0 & 0 & & 1 & 0 & 1 & 1 & 4 & D & $53 \%$ \\
\hline M & 0 & 0 & ) & 0 & 1 & 0 & 1 & 1 & & 3 & 3 & 3 & 2 & 0 & 15 & $2,69 \%$ \\
\hline $\mathbf{P}$ & 0 & 0 & 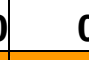 & 0 & 0 & 0 & 0 & 0 & & 0 & 1 & 5 & 5 & 0 & 11 & $1,97 \%$ \\
\hline A & 0 & 0 & ) & 1 & 0 & 0 & 1 & 0 & & 2 & 3 & 7 & 10 & 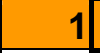 & 25 & ,48\% \\
\hline$E$ & 1 & 0 & 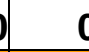 & 0 & 1 & 0 & 0 & 0 & & 1 & 2 & 0 & 4 & 0 & 9 & $1,61 \%$ \\
\hline$F$ & 1 & 0 & ) & 0 & 0 & 2 & 3 & 3 & & 2 & 0 & 0 & 0 & 0 & 12 & $2,15 \%$ \\
\hline $\mathbf{S}$ & 0 & 0 & 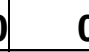 & 0 & 0 & 0 & 1 & 0 & & 0 & 0 & 3 & 6 & 0 & 10 & $1,79 \%$ \\
\hline 0 & 0 & 4 & 1 & 1 & 3 & 2 & 12 & 12 & 11 & 13 & 14 & 30 & 12 & 4 & $4 \quad 118$ & $21,18 \%$ \\
\hline A & 0 & 0 & 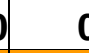 & 0 & 0 & 0 & 1 & 0 & & 1 & 0 & 2 & 1 & 1 & 7 & $1,25 \%$ \\
\hline |G & 4 & 1 & L & 1 & 0 & 1 & 5 & 11 & & 2 & 8 & 7 & 18 & 2 & 59 & $10,59 \%$ \\
\hline IS & 0 & 0 & 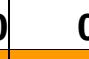 & 0 & 0 & 0 & 0 & 1 & & 1 & 0 & 4 & 2 & 0 & 8 & $1,43 \%$ \\
\hline IT & 0 & 0 & ) & 0 & 0 & 0 & 0 & 0 & & 2 & 0 & 2 & 0 & 5 & 10 & $1,79 \%$ \\
\hline A & 1 & 1 & 4 & 0 & 0 & 1 & 1 & 0 & & 2 & 4 & 3 & 1 & 2 & 17 & $3,05 \%$ \\
\hline$B$ & 1 & 0 & ) & 0 & 0 & 0 & 0 & 0 & & 0 & 0 & 0 & 0 & 0 & 1 & $0,17 \%$ \\
\hline E & 0 & 0 & 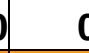 & 0 & 1 & 1 & 1 & 1 & & 2 & 11 & 2 & 3 & 1 & 26 & $4,66 \%$ \\
\hline | | & 0 & 0 & ) & 0 & 0 & 1 & 0 & 0 & & 0 & 0 & 0 & 0 & 0 & 1 & $0,17 \%$ \\
\hline $\mathbf{R}$ & 0 & 0 & 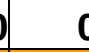 & 0 & 1 & 3 & 3 & 2 & & 10 & 5 & 4 & 2 & 0 & 32 & $5,57 \%$ \\
\hline J & 3 & 3 & 3 & 0 & 2 & 3 & 2 & 7 & & 7 & 6 & 3 & 10 & 2 & 50 & $8,97 \%$ \\
\hline $\mathbf{N}$ & 0 & 0 & 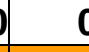 & 0 & 0 & 4 & 0 & 0 & & 0 & 2 & 2 & 5 & 0 & 9 & $1,61 \%$ \\
\hline 0 & 0 & 0 & ) & 0 & 1 & 0 & 0 & 1 & & 0 & 1 & 2 & 0 & 3 & 13 & $2,33 \%$ \\
\hline R & 0 & 0 & 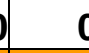 & 0 & 0 & 0 & 1 & 0 & & 1 & 1 & 10 & 4 & 2 & 19 & $3,41 \%$ \\
\hline 2S & 0 & 0 & 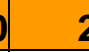 & 2 & 0 & 3 & 0 & 3 & & 2 & 1 & 4 & 2 & 0 & 17 & $3,05 \%$ \\
\hline$C$ & 0 & 0 & 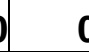 & 0 & 0 & 0 & 0 & 0 & & 0 & 1 & 1 & 1 & 1 & 4 & $0,71 \%$ \\
\hline E & 0 & 0 & c & 0 & 0 & 0 & 0 & 0 & & 0 & 0 & 0 & 0 & 1 & 1 & $0,17 \%$ \\
\hline $\mathbf{P}$ & 1 & 1 & 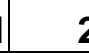 & 2 & 0 & 3 & 3 & 3 & 6 & 5 & 9 & 20 & 11 & 1 & 65 & $11,66 \%$ \\
\hline 0 & 0 & 0 & 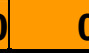 & 0 & 1 & 0 & 0 & 1 & & 0 & 0 & 3 & 2 & 0 & 8 & $1,43 \%$ \\
\hline otal & 8 & 10 & & 7 & 11 & 20 & 35 & 48 & 39 & 56 & 72 & 119 & 105 & 27 & 7) 557 & $100 \%$ \\
\hline
\end{tabular}

Fonte: DDH/CGDI/DIREX/DPF 